\title{
The Role of the Train Station in the Image Formation of the Early Republican Ankara
}

\author{
Segah Sak' and Inci Basa'
}

\begin{abstract}
Depending on the assumption that buildings play the fundamental role in the formation of cities and their image, this study investigates the contribution of the Train Station to the formation of Ankara and its image in the early years of the Turkish Republic. The spatial entity of the station reflected the intended modern identity of the new state. Orienting the movement and development within its setting, the building constituted an indispensable element of the structure of the city. It acted as an immediate stimulus for the perception of the city and as a mediator for the creation of city's image. As a building of prestige, it accommodated contemporary practices and provided civilized conditions for the whole public. Consequently, the station had a significant effect on the social and spatial formation and mental re-formation of Ankara.
\end{abstract}

\section{Keywords}

city image, Ankara, train station, urban formation, capital city

The city is, by no means, a static entity; it is created and re-created through time by the humankind. As it is experienced, its function, body, and essence change with the ever-shifting social, cultural, political, and economical conditions. Changes that the cities encounter are not always slow and ordinary ones; political structures are apt to change suddenly, if not the economical, social, and cultural structures. Just as Blockmans observed, new state regimes endeavor to transform the cities "to provide an adequate expression of their ideologies." Accordingly, architecture is considered as a political tool used to shape the nation physically and socially. In this sense, Ankara, the capital of Turkey, experienced a sudden and deliberate development in the early years of the republic to ensure a particular sociocultural formation and to create an image for the city. Only by doing so, the intended ideology could be constructed, distributed, and represented. Consequently, as in any city experiencing a political change, the new state used public spaces as "a stage to express their own messages."2 Urban public spaces were conceived as the concrete realization of the ideals of the modern republican Turkey. Autonomous architectural thought had limited impact upon the spatial formation of the new capital; architectural culture was, moreover, correlated with the political agenda of the new regime. Ideological attitude determined

\footnotetext{
'Bilkent University, Ankara, Turkey
}

\section{Corresponding Author:}

Segah Sak, Bilkent University, Faculty of Art, Design and Architecture, Department of Interior Architecture and Environmental Design, 06800, Bilkent, Ankara, Turkey

Email:segah@bilkent.edu.tr 
architectural practice and interpreted new physical form. On the other hand, built space was the simultaneous occurrence of a proposal for a new and unique image. The city and the urban life were (re)constructed on a new basis and at another scale for a new nation. The formation of Ankara and formation of its image were coeval; that is what makes this capital a remarkable case to trace out the system of people and places in the context of city image. ${ }^{3}$

The concept of "the image of the city" implies people's mental pictures of the city, that is, what they construct in their minds internalizing their experiences, observations, and perceptions. Lynch explains that "the need to recognize and pattern our surroundings is so crucial, and has such long roots in the past, that this image has wide practical and emotional importance to the individual." Importance of image is more extensive though, as it is related to not only individual but also public: city image is affected intensively by, and it has a considerable effect on, collective experiences and meanings. Nature of the new capital as a civic symbol of the new regime puts forward the notions of collective experience and meaning in the public domain as ultimately important issues.

The city image, just like the city itself, is a multidimensional entity. It is notably complex in nature, thus, as an object of research, it comprises a considerable number of tendencies, ways, patterns, and methods. Research aiming at understanding the city image deal with different aspects of urban knowledge. Lynch sets forth three components-identity, structure, and meaningwhich together form the image of the city. ${ }^{5}$ In his work, he concentrates on the physical qualities of a city that are likely to evoke a strong image of the city in the observers. ${ }^{6}$ Supported by the concept of readability of the city, Lynch's understanding of the image of the city is strongly connected with the perceiving consciousness of the readers of the city. His argument predominantly emphasizes the physical environment and perception of the individual. It inevitably overshadows the discursive bond between the spatial formations and the collective conceptualization in citizens' minds. Physical form of the urban fabric and its visual attributes may not be adequate to conceive the creation and conditioning of the citizens' image formation. Depicting the specific social and ideological context of the physical shaping is necessary for a comprehensive scope. Lynch's approach can be accomplished with overcoming his narrowed assumption that urban image and physical form's perceptual cognition are equal. Indeed, an elaborate mental constitution of urban image is necessarily processed by conceptualization of this urban space.

Following Lynch's studies, Nasar proposes the notion of the "evaluative image of the city.", This study mainly elaborates the characteristics of the city that affect people's evaluation of the city positively. According to him, naturalness, upkeep, openness, historical significance, and the order of the city determine likeability. Well-being related to any of those characteristics help to the creation of a positive city image. ${ }^{8}$ Nasar demonstrates a state of contentment, which is inseparable with desirable qualities of urban life experienced by citizens. Yet, decisive and general qualities of urban life in his proposition require being reevaluated and specified in different contexts. An awareness of plurality and variability of effects should inform the identification of image constitution both in the distinctive perspectives toward historical substance and in the dynamics of contemporary spatial order.

Variety of the components reveals the multifaceted essence of the image construction process. Eventually, what Lynch emphasizes are the structure of the city and citizens' perception of it, whereas Nasar places special emphasis on ideally conditioned environment and inhabitant relationship.

Essentially, our image of the city is a result of any kind of perception. As Boyer indicates, a frozen image is created by the spatial order of the city and this image evokes the memory and amazement of the spectator. ${ }^{9}$ What determine the image of the city are the physical qualities as well as what it reflects, such as "the social meaning of an area, its function, its history, or even its name." 10 This leads us to the understanding of the nature of the image as complex, 
multisensorial, and abstract, because the image encapsulates beliefs, knowledge, opinions, and feelings about the city as well as the visual perceptions. ${ }^{11}$ This study adopts an approach that handles the concept of the image of the city with a broad perspective. The concern here is neither a structure-dependent image nor a favorable image. Rather, with respect to the case of Ankara, it is a specific image that is dependent on identity and meaning, as well as structure. These determinants may emphasize different premises in response to different cities, changing contexts, and circumstances. Any research on the formation of the image of Turkish capital of early republican times necessarily places a high priority on the drastic changes in political, social, and cultural structure.

Existences of architecture and cities are mutually dependent. ${ }^{12}$ Correspondingly, the most obvious features of the city are the buildings and structures. ${ }^{13}$ As Lynch states, the manmade characteristics and problems of the city usually override the underlying topography and the preexisting natural setting. ${ }^{14}$ Thus, it is possible to claim that the city, as a manmade place, reveals its entity through its built structures, and therefore, buildings have about the biggest effect on the image of the cities. Buildings determine the structure and identity of the city, and moreover they accommodate individual and collective experiences leading to the attachment of meaning. Urban identities today are not entirely identified with materiality of spaces; reflections of information technologies and processes are, for instance, woven into citizens' urban conceptualization. Yet, offices, stations, schools, hospitals, cinemas, museums, residential buildings, and the spatial order are powerful marks of urban identity.

Train stations constitute one of the most important nodes in the city because "people heighten their attention at such places and perceive nearby elements with more than normal clarity." 15 The Ankara Train Station was among the most significant urban spaces of Ankara in the early years of the republic due to its cohesive public role. Its spatial entity reinforced the identity intended to be created and constituted an important component of the structural system of the city. Its significance depended also on the practices that it encouraged and the experiences that it fostered. Moreover, the building's stylistic expression embodied symbolic meanings. Its monumental and modern aesthetic represented both the power of the republican ideology and the young Turkish Republic's radical break with the Islamic Ottoman culture. Based on these assumptions, Ankara Train Station, with its physical and semantic attributes, played an implicit yet important role in the spatial and social formation and thus in the image formation of early republican Ankara.

\section{Formation of Ankara and Its Image}

Ankara, located at the center of Anatolia, has a long history reaching back to the ancient times; it accommodated the civilizations of Hittites, Frigs, Hellenes, Byzantines, Seljuks, and Akhis. At the beginning of the fifteenth century, it became part of the Ottoman Empire. During the Ottoman Period, it was considered to be the most important city of production, ${ }^{16}$ in which Ankara wool (sof) was manufactured and traded. Ankara of the Ottoman Empire accommodated the wealthy merchants who may be considered as belonging to the bourgeois class, ${ }^{17}$ thus, the city had the economical power to be included in the list of significant cities of the era. Ankara, however, preferred to exist as a rational, modest city with its elaborate housing and simple public buildings ${ }^{18}$ such as mosques, bedestens (closed bazaars), and hostels for itinerant merchants. Yet, the primary elements of the morphology of the city were the traditional houses within the citadel. $^{19}$

At the end of the nineteenth century, Ankara, as a trade center, started to lose its importance due to the flow of industrial products from the West to the country. ${ }^{20}$ Furthermore, it was naturally being affected by the regression of the Ottoman Empire that was losing its centuries-long 
power and was being dragged in to chaos under the influence and pressures of the outer world. ${ }^{21}$ Still, when the city became a station in the developing network of railroads in $1892,{ }^{22}$ it showed signs of recovery owing to the dynamism that railroads provided, but its economical activity and power did not have the chance to actually revive. ${ }^{23}$

At the beginning of the twentieth century, Ankara could be distinguished from a village only by its scale and the remains of its citadel. ${ }^{24}$ Furthermore, in 1917, an expansive fire instigated the decline of the city. ${ }^{25}$ Expectedly, the circumstances got harder for the citizens when the city was chosen by Turkish nationalists as the military center of the War of Independence. ${ }^{26}$ On April 23, 1920, the Turkish National Assembly (TBMM) was founded in Ankara, and the city unofficially became the center of the state. This decision primarily depended on its strategic location being distant enough from the center of the Empire and the foreign forces and central enough to control the periphery. Second, the city was a part of the railway network and it had a telegraph system, which together provided the urgent communication and transportation for the military and civil forces. ${ }^{27}$ Now, although the mission of the city was impressively important, the city itself, suffering from the exceptional and difficult conditions of the war, did not really have the qualities to reflect such a significance.

When the War of Independence came to a successful end, Ankara, with its nationalist citizens and their contribution to the struggle for independence, had started to be considered as an essential part of the independence history of the Turks. Ankara, on October 13, 1923, just a few weeks before the foundation of the new republic, was announced to be the capital as a symbol of returning back to Anatolia and as a challenge to Istanbul. ${ }^{28}$ Later, this decision was going to be enshrined in the third article of the constitutional charter of the Turkish Republic, while the fourth article would indicate its changelessness.

Now, it was time to build the new republic established on the secular nationalist doctrine as the cultural foundation and overall ideology of Turkish policy. Constructing a new culture and ideology meant reforming the whole way of living in the city. By doing so, the regime was going to secure its own existence and build a "modern image" for its reputation and acknowledgment among the other modern countries. The civilizing ambition of the nationalist republican leaders was to be implied primarily in the cities, where state power could be applied and displayed effectively, rather than the countryside. ${ }^{29}$ Ankara, as the capital, became the fundamental stage of the country wherein the desired secular ideology and modernity would be actualized and exhibited. Furthermore, it was going to constitute a model for other Anatolian cities, ${ }^{30}$ with its urban and spatial features as well as in its social and cultural structure. ${ }^{31}$ Both the activities and the setting in which those formations were going to occur had to fit the ideals of the new government. Thus, the city as a representation of the new republic (with its entity and its society as a system) was going to be "Westernized," "modern," and "secular" at the level of "contemporary civilizations."

As Rossi explains, "architecture gives concrete form to society and is intimately connected with it." ${ }^{, 32}$ That is why we cannot evaluate any society or city independent from its architecture. On reflection, architectural essence can be best envisaged by its social bonds. "Architecture, by its very nature, has always been a powerful symbol as well as an effective instrument of reform and change in the modern world. ${ }^{, 33}$ Only when the physical space is created can the new facilities come into existence in urban life. Accordingly, in Ankara, all the activities and the citizens, at the outset, needed to be accommodated in appropriate settings in the service of the envisions of the new state. As Erendil and Ulusoy state, to establish the nation-state and to create the consciousness of the citizens, the highest importance was given to the urban areas as the "seedbed" for creating the modern society. ${ }^{34}$ And the setting created in Ankara aimed at a high culture based on modern living standards rather than the traditional living standards. ${ }^{35}$ On the other hand, the city with its architectural identity was a visible symbol of the intended nation and the republic. ${ }^{36}$ 
For this reason the identity proposed for Ankara can be considered as "a 'concrete' manifestation of the high modernist vision." ${ }^{37}$ An intrinsic expression of the modern epoch had to be attained by new planning principles, so creation of a collective feeling of contemporariness was a deliberate objective. Political task of raising public's awareness on modern forms of life found its definite expression in architecture.

At the early years of the republic, in spite of all revolutionary formations, the architectural tendencies focused on the revivalist Ottoman style. There was a need for an urgent development of the urban texture within the limited financial conditions of the country. The most significant professional architects of the period, Kemalettin Bey (1870-1927) and Vedat Tek (1873-1942), were invited from Istanbul to Ankara to design and construct the first official and public buildings and urban spaces of the new state. Ottoman features and details dominated the very first republican years' architectural language. Modern construction techniques were used, but the traditional elements, such as pointed arches, domes, and wide eaves, were significant in the overall compositions. The actual introduction of the modern style to the architectural culture of the country occurred during the 1930s. ${ }^{38}$ This process coincides with the arrival of foreign architects led primarily by Clemenz Holzmeister (1886-1983), Bruno Taut (1880-1938), and Ernst Egli (1893-1983). They designed not only large-scale administrative and public buildings, but also actively participated in the architectural education. ${ }^{39}$ There were a limited number of Turkish architects who found the opportunity to contribute to the architectural identity of the new capital. Şekip Akalın (1910-1965), the architect of the train station, was one of these architects. With the appearance and under the influence of foreign architects, a modernist perspective was developed in the architectural practice. The Ottoman traces were completely eliminated from the architectural practice and conception of the Turkish architects as well. The aim of the implementation of a western and modernist style was to prove that "Turkey was a modern European nation with no resemblance to the exotic and orientalist aesthetic tropes by which the Ottoman Empire typically had been represented in the past." ${ }^{, 40}$ Under the influence of German-speaking architects, Middle European modernism dominated the architectural practice of the period (see Figures 1 and 2).

The Lörcher Plan (1924-1925) was the first plan of Ankara. ${ }^{41}$ Lörcher created a plan envisioning two phases: the first phase was the creation of the plan of the Old City, the second phase was the design of the New City, the governmental center, Çankaya. ${ }^{42}$ The plan constituted the foundation for the development of the infrastructure and the early settlements that were needed during and after the War of Independence. But it did not satisfy the high expectations and needs of the new capital.

In 1928, German city-planner Hermann Jansen (1869-1947) won the International Competition of Ankara Master Plan. The plan was approved in 1932 and implemented until 1939. Despite the interventions depending on many speculations and the population's rapid growth, Jansen's plan constituted a basis for the general space allocation of the city.

When Ankara was declared the capital, it was a small town with a population of twenty thousand located on the skirts of the citadel. The first parliament building (originally built as the Headquarters of the Committee of Union and Progress in 1927) was located between Ulus ("Nation") Square, the most important meeting point of new and old citizens of Ankara, ${ }^{43}$ and the old train station. The need arose to accommodate important visitors, governors, bureaucrats, and intellectuals, ${ }^{44}$ and Ankara Palace (1924-1927) was built facing the parliament building. It became an indispensable social space. ${ }^{45}$

Since the most important buildings, the parliament building and the train station, were located in the Ulus region, the old city was accepted as the origin of the development of the city. The area between the Train Station and Ulus Square had already been experiencing diverse construction when the Jansen Plan started to be implemented. The city expanded toward the south of the Old City, built around the Citadel. Atatürk Boulevard became the axis that connected the Old City 


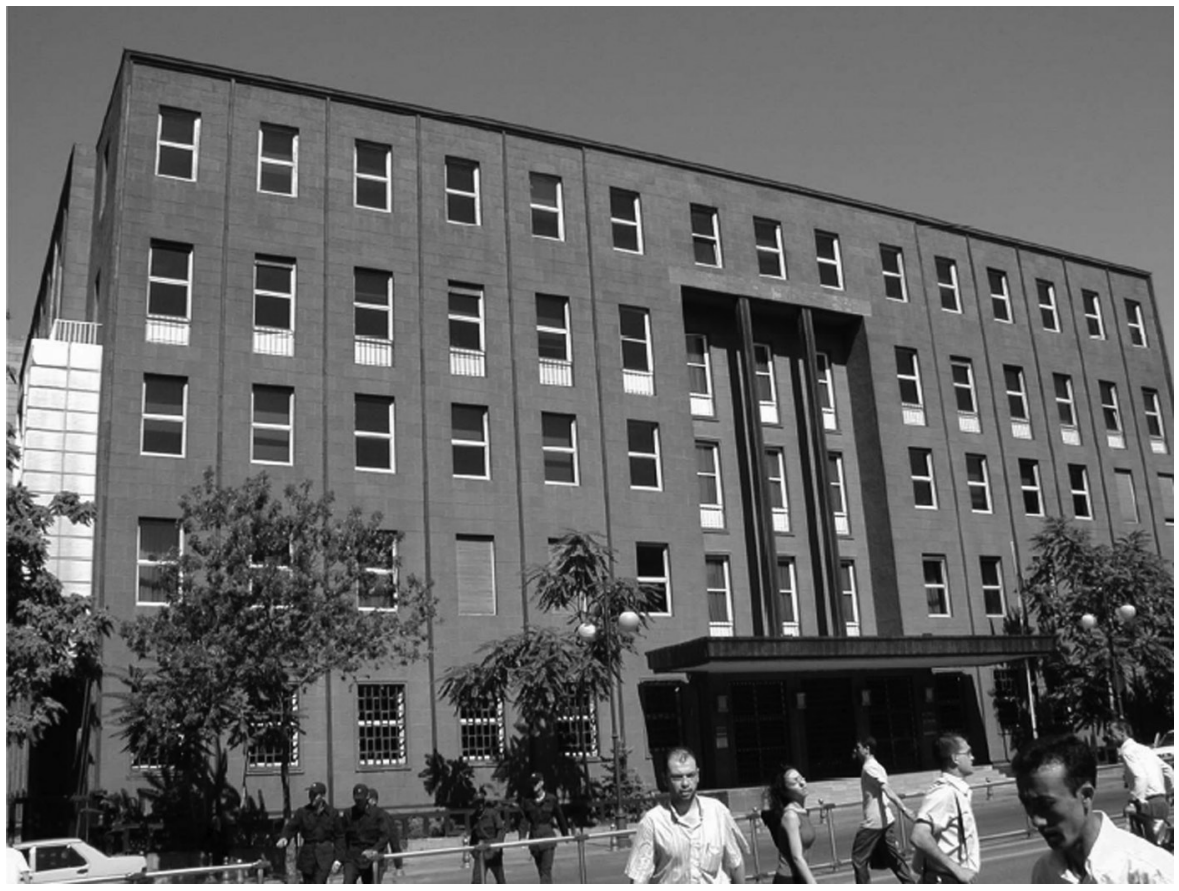

Figure I. Merkez Bank. Building designed by Clemens Holzmeister, constructed between 193 I and I933. Source: Photograph taken by Inci Basa.

and the New City. Along this boulevard, the newly founded banks, the educational institutes, and the ministries were built, and eventually extended to the south, reaching the residence of the President in Çankaya.

The Jansen Plan proposed eighteen residential areas located mostly toward the east and the west, each with their own design of space allocation. ${ }^{46}$ Proposed dwellings were, at most, threestory houses with gardens, whether they were adjacent or separated. ${ }^{47}$ The spacious character of the residential areas maintained the openness of the city.

In addition to the construction of urban structures, there was intense effort to green the main boulevards of the city. This rapid greening of the bare land balanced the intense construction within the city. Gençlik Parkı (Youth Park) (1936-1937) (see Figure 3) was constructed in the area created by Talatpaşa Boulevard, Station Road, and Atatürk Boulevard with the aim of maintaining the visibility of the Citadel by creating green zones.

Construction of the capital distant from the remains of the Ottoman Empire in a "deserted" setting was considered to express a symbolic meaning. Ankara, as the capital of the republic removed from Istanbul, signified a state that had broken its ties to the old empire. ${ }^{48}$ For the state, a rapidly developing capital, with its own dynamism in the aforementioned setting, also meant "existence" and a successful "struggle" for dominance over the imperial and Islamic attributions of the Ottoman Empire.

For the case of Ankara, the revolutionary social and political transformation and radically changing circumstances reshaped the lives of the citizens and accordingly conveyed a collective 


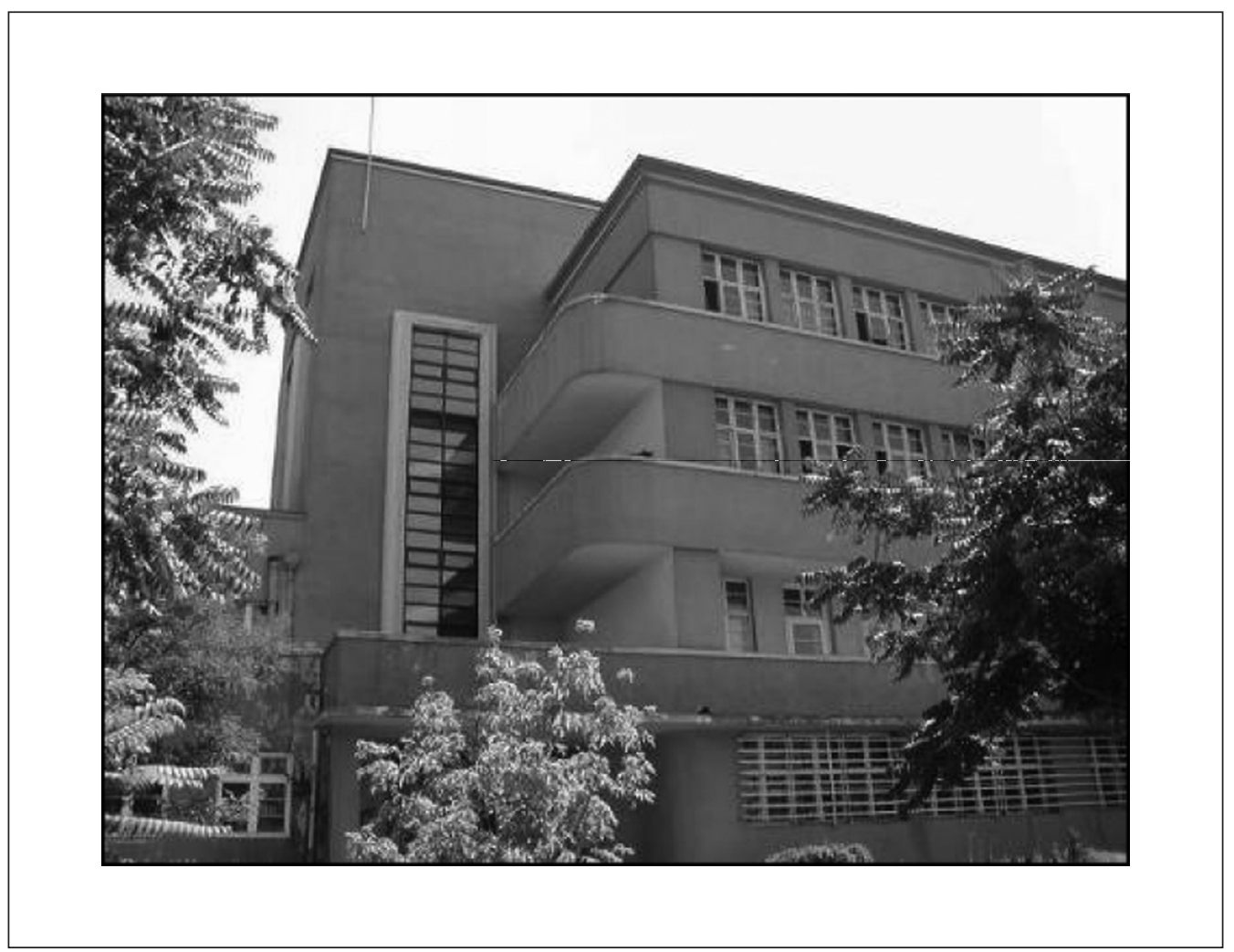

Figure 2. Institute for Girls. Building designed by Ernst Egli, constructed in 1930.

Source: Photograph taken by Inci Basa.

meaning. For its citizens, as for the state, Ankara meant "being civilized." The citizens of the capital Ankara were now living in a "modern" setting, provided with "Western standards." Their consciousness was heightened by contemporary urban services and the facilities offered.

On the other hand, perhaps the most important aim of this enthusiastic construction was to ensure the appreciation of the "outer" world. The changes in the attitude of the news and media articles published during the construction process of Ankara offered convincing proof that the "outer" world was impressed by the construction of the young capital.

The intended spatiality being created in Ankara carried a particular meaning for the state and its people. This meaning was best revealed in the urban public spaces of the city, creating a collective image of the city. This insight leads to the investigation of certain urban artifacts to gain a deeper understanding of the interface between the social and spatial formulations within the city and its reformation in the minds of people.

\section{Location of the Train Station}

The train station was located in the southern part of the Ulus region (see Figure 4). According to Lynch, the images of different regions of a city are not equal because there are "dominant figures and more extensive backgrounds, focal points, and connective tissue." 49 In Ankara, Ulus was one of those regions with all the significant buildings and the collective memories within the area. The train station was an indispensable element of the setting as it constituted the fundamental 


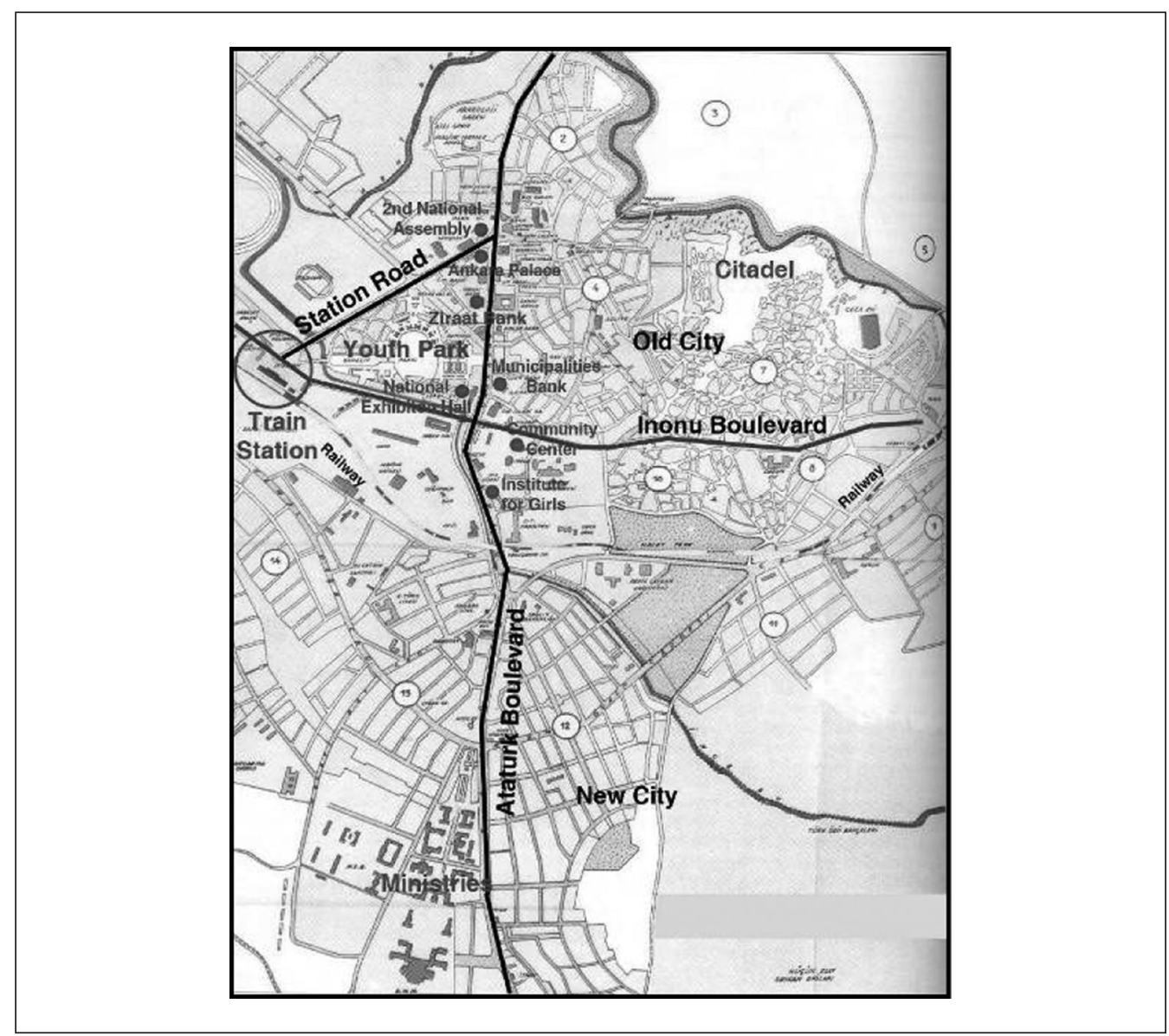

Figure 3. Location of the train station in the urban scheme.

Source:Adapted from Hüseyin Orak, Türkiye Kılavuzu (Ankara: Hüseyin Orak, 1946).

activities in the city center, which depended on the capital's function. Furthermore, it accommodated various activities within, built as a complex comprised of the station, a casino-restaurant, and clock tower (see Figure 5).

The Station and the Parliament were connected by the Station Road. It headed to Ulus Square, the node on Atatürk Boulevard connecting the Old City and the New City. Station Road was the route of elite visitors entering the city from the train station, being accommodated in Ankara Palace, and sightseeing the citadel. The triangular area bounded by Station Road and Atatürk Boulevard was adorned with various public buildings. ${ }^{50}$ Ankara Palace was built facing the Parliament Building, on the opposite side of Station Road (see Figure 6). It was not only a hotel accommodating native and foreign bureaucrats, but also a social space assembling urban activities within its walls. Many well-known balls attended by the elites were organized in this first saloon of the city. Old modest citizens watched from Station Road the arrival of guests of the balls, partly in curiosity and envy and partly with displeasure. ${ }^{51}$ Thus, the setting not only created the intended identity of assembling urban artifacts and a modern society, but also influenced the dynamics within the society. 


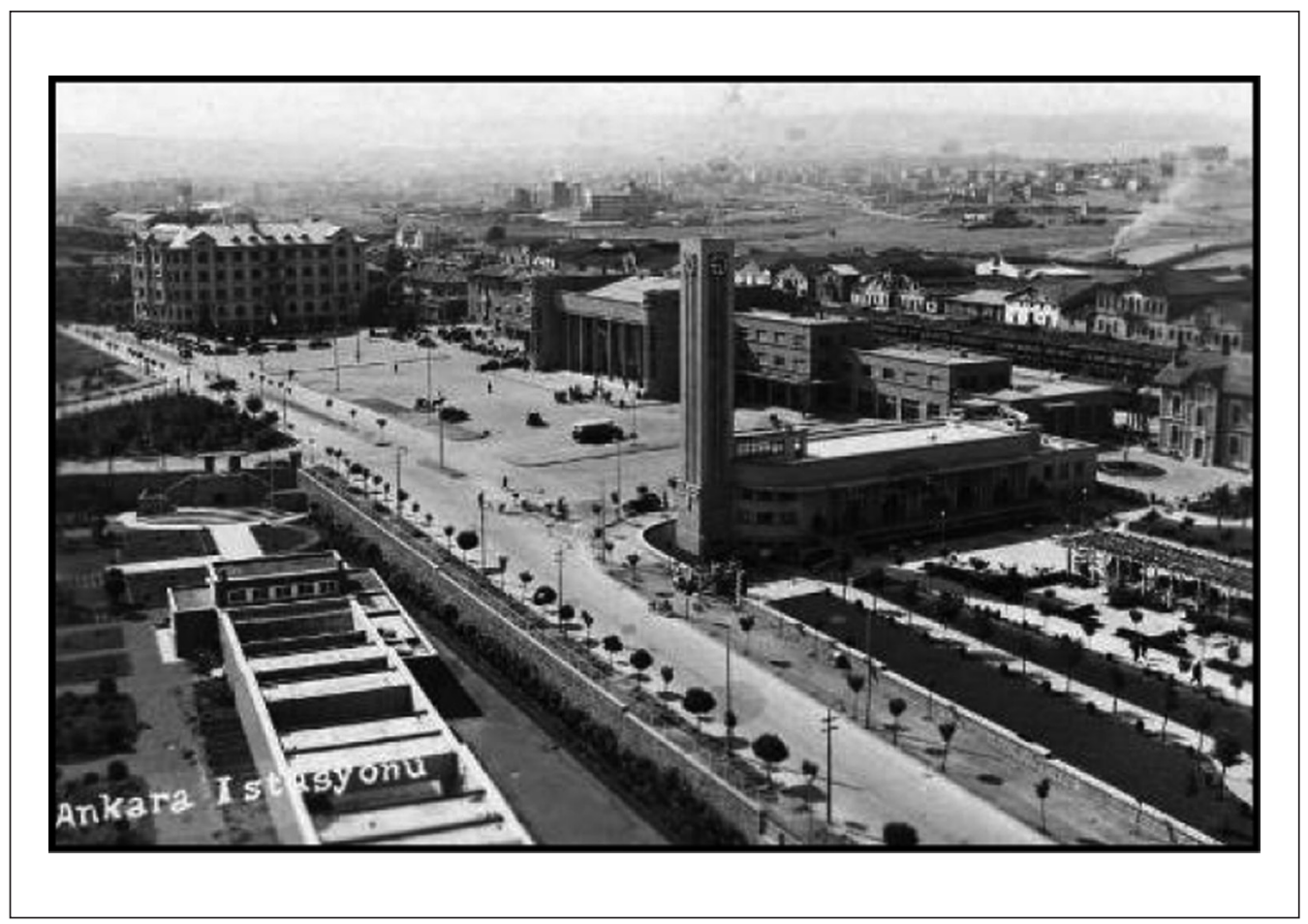

Figure 4. The station and the casino (Gar Gazinosu).

Source: Ankara Posta Kartları ve Belge Fotoğrafları Arşivi Kataloğu, edited by Ozan Sağdıç, (Ankara: Belko, 1994), 2 I.

The first design of Jansen for the mentioned area envisioned a trade center. However, the north portion of the area was allocated for buildings, while the southern portion was turned into a park. Although Jansen had a park proposal, it was designed by landscape architect and planner Theo Leveau, an employee of the Ministry of Public Works. ${ }^{52}$ Gençlik Parkı (Youth Park) was intended to provide desired greenery and water in the arid setting. Built across the train station, it displayed an ideal scene serving the task of welcoming all visitors, reflecting the modern and appealing atmosphere of the city, and being an urban park representing the ideals of the new regime..$^{53}$

In the early years of the republic, parades were marshaled on Station Road. ${ }^{54}$ This was partly due to the functional and symbolic qualities of the road. The intensity of the potential of creating the intended image of this area can also be considered to be a fundamental factor in organizing social meetings such as parades and celebrations. The setting portrayed an intense composition of public places.

\section{Architectural Characteristics of the Train Station}

Train stations of the industrialized modern world were mostly designed as gates to cities and as "microcosms" of cities. ${ }^{55}$ The transportation was primarily provided by railroads, and thus, the main entrances of cities were the train stations. Although their importance is declining with the development of highways and airways, they still constitute important nodes of cities $^{56}$ as they have shaped their milieu. 


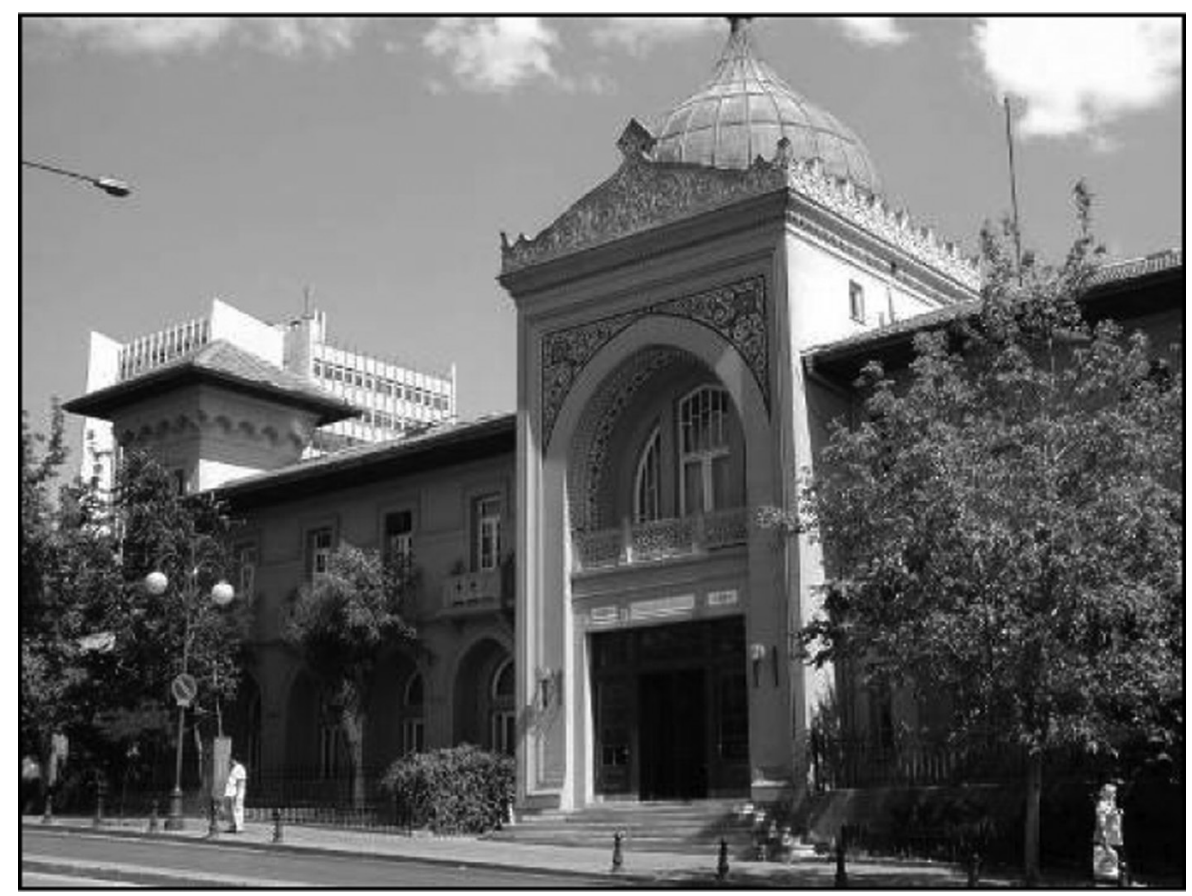

Figure 5. Ankara Palace.

Source: Photograph taken by Inci Basa.

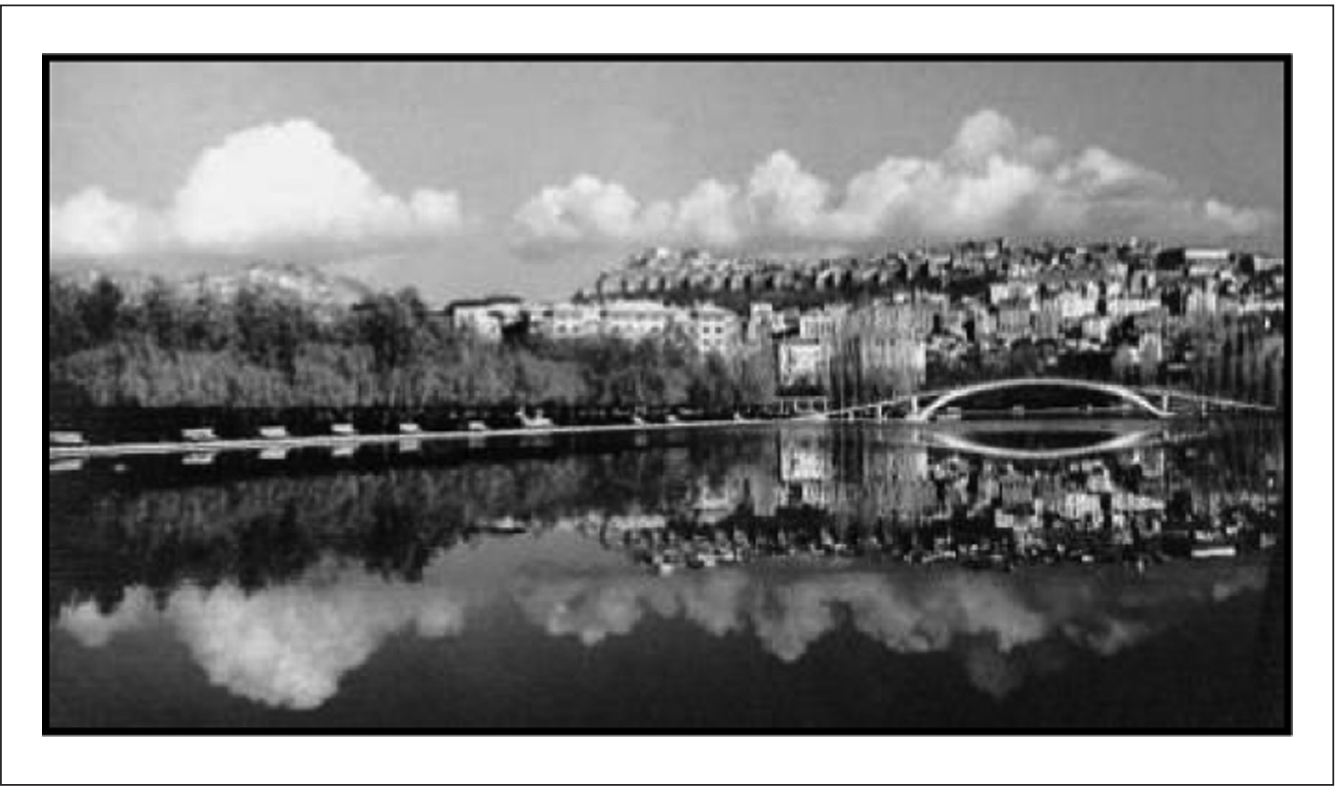

Figure 6. A view from the Youth Park.

Source:“I 989-1999 Century,” T.C. Başbakanlık Basın-Yayın ve Enformasyon Genel Müdürlüğü, 2000, http://www.byegm.gov. tr/YAYINLARIMIZ/yuzyil/I940-1949.htm. 


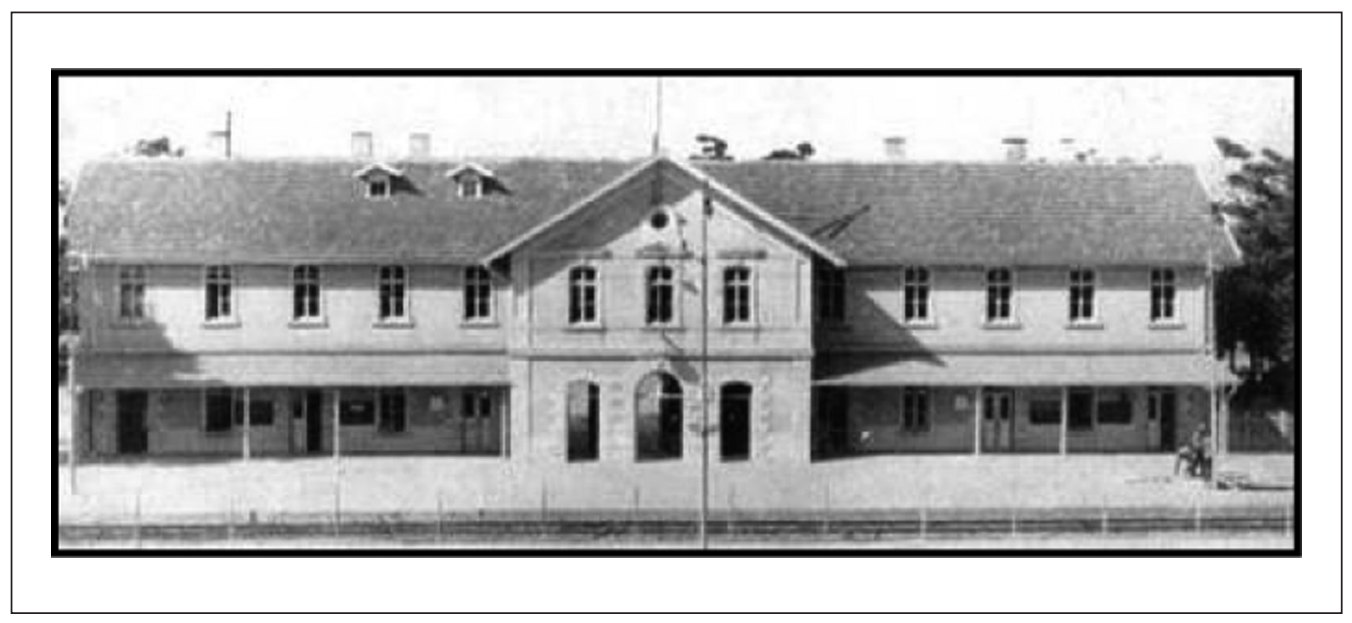

Figure 7. The facade of the old train station seen from the railway. Source:T.C.D.D., Fotoğraflarla Yeni Ankara Garı [New Ankara Train Station in photos] (Ankara:T.C.D.D. Genel Müdürlüğü, 2006, original work published in 1937), I 25.

Likewise, Ankara Train Station was considered to be "the grand gate of Ankara." $"$ In the early years of the republic, it was not possible to go anywhere other than by train. Its declaration as the capital resulted in a flow of visitors and new residents to the city. But the old train station (see Figure 7) was sufficient neither in its physical qualities nor its function. Farrère tells that the old train station was provincial and did not provide the feeling of confidence as any European capital would. ${ }^{58}$ For that reason, the old station was replaced with a new one. A special sensitivity was shown in the station's design and its construction despite severe economic conditions imposed by the war. Railways were the primary mode of transportation until the 1950s. Thus, the train station retained its important role until then.

The new station was designed by Şekip Akalın in 1934. He was among the Turkish architects who embraced the modern architectural style. Construction of the train station started in 1935 and was completed in 1937. It was one of the earliest buildings designed by a Turkish architect in a contemporary architectural style (see Figure 8 and 9). The building was detached from all the adornments of the Ottoman style. It was pure in terms of form and facade. On the other hand, it had splendid dimensions, based on its symbolic function as the gate of the capital. ${ }^{59}$

The station building rests in a northwest/southeast direction, its symmetric horizontal volume measuring 150 meters. ${ }^{60}$ It has a reinforced concrete structural system. The facades are covered with Ankara stone, made of granulated pink andesite and cement that was used frequently within and around the citadel. ${ }^{61}$ The Station Casino building and its thirty-two-meter high clock tower (see Figure 11), a favorite architectural landmark, were also built using the same structural system. These two volumes, the station and the casino, are connected by three pairs of columns arrayed in a curved line (see Figure 10). The new urban complex comprised of these buildings offered a modern spatial experience similar to that of its western contemporaries.

Entrance to the main building is provided from the longitudinal facades through the middle axis (Figure 12). Entering from Station Road, there are three steps and the ten-meter high columns in front the main hall (see Figure 13). The columns and the horizontal strip at the top are made from local Hereke stone. The hall measures $23 \times 33$ meters and is twelve meters high, illuminated by the wide openings on the middle axis and by the artificial lighting on the ceiling (see Figure 14). The window and door frames exhibited a careful detailing of wood, frosted glass, and chrome handles. The signs within the station were also lettered in chrome. There are 


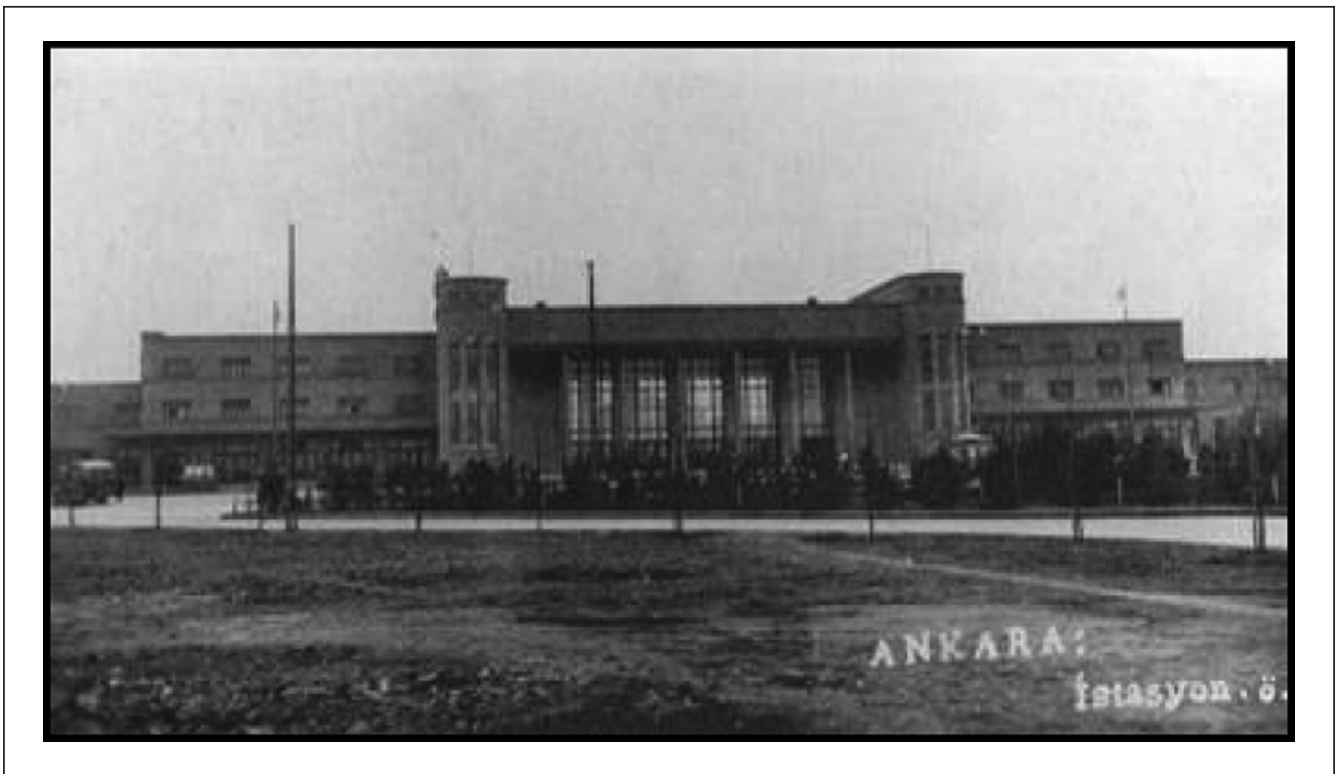

Figure 8. The front view of the train station.

Source:Ankara Posta Kartları ve Belge Fotoğrafları Arşivi Kataloğu, edited by Ozan Sağdıç (Ankara: Belko, 1994), 20.

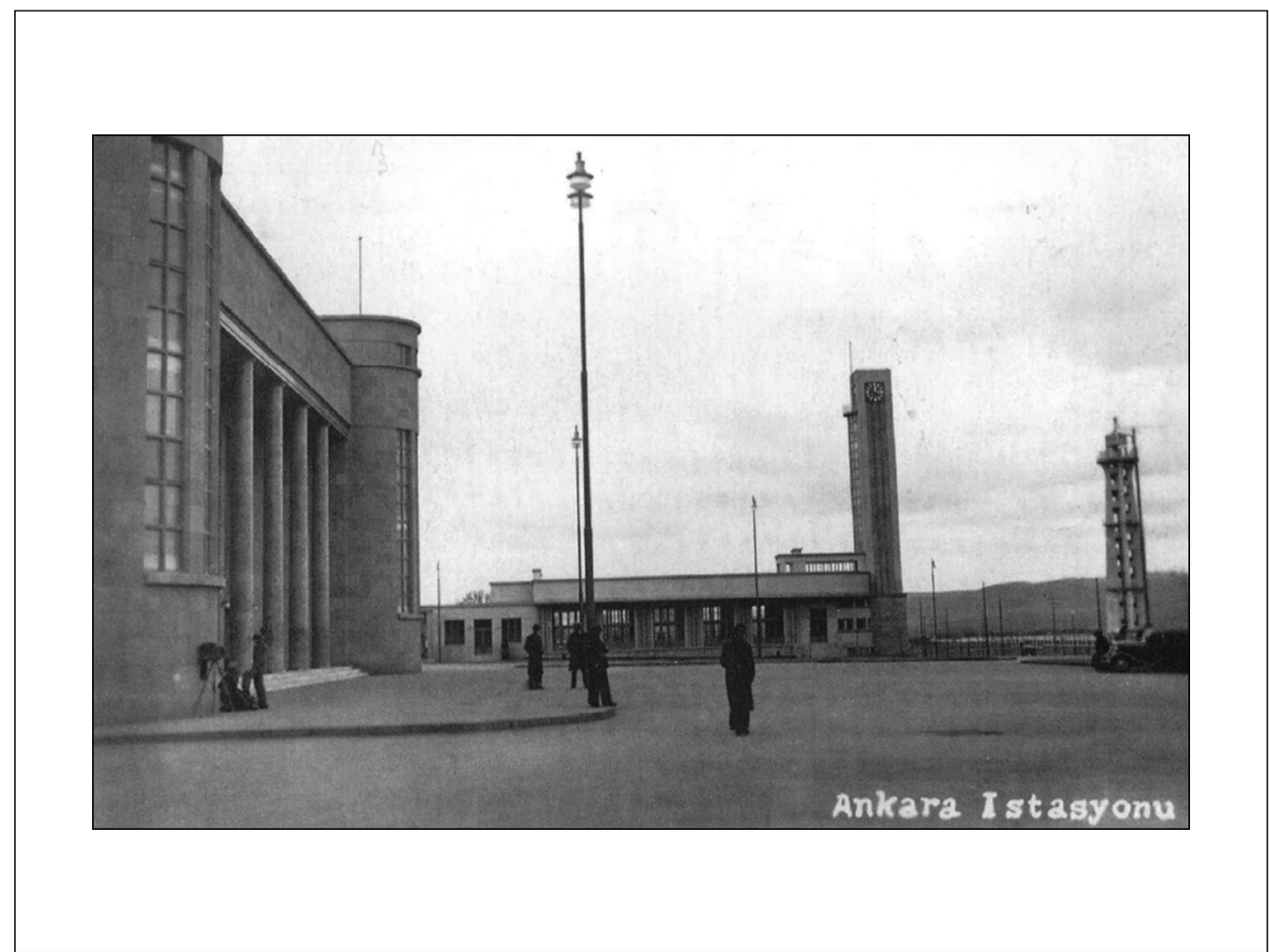

Figure 9. The station complex built on a deserted land.

Source:Ankara Posta Kartları ve Belge Fotoğrafları Arşivi Kataloğu, edited by Ozan Sağdıç (Ankara: Belko, 1994), 20. 


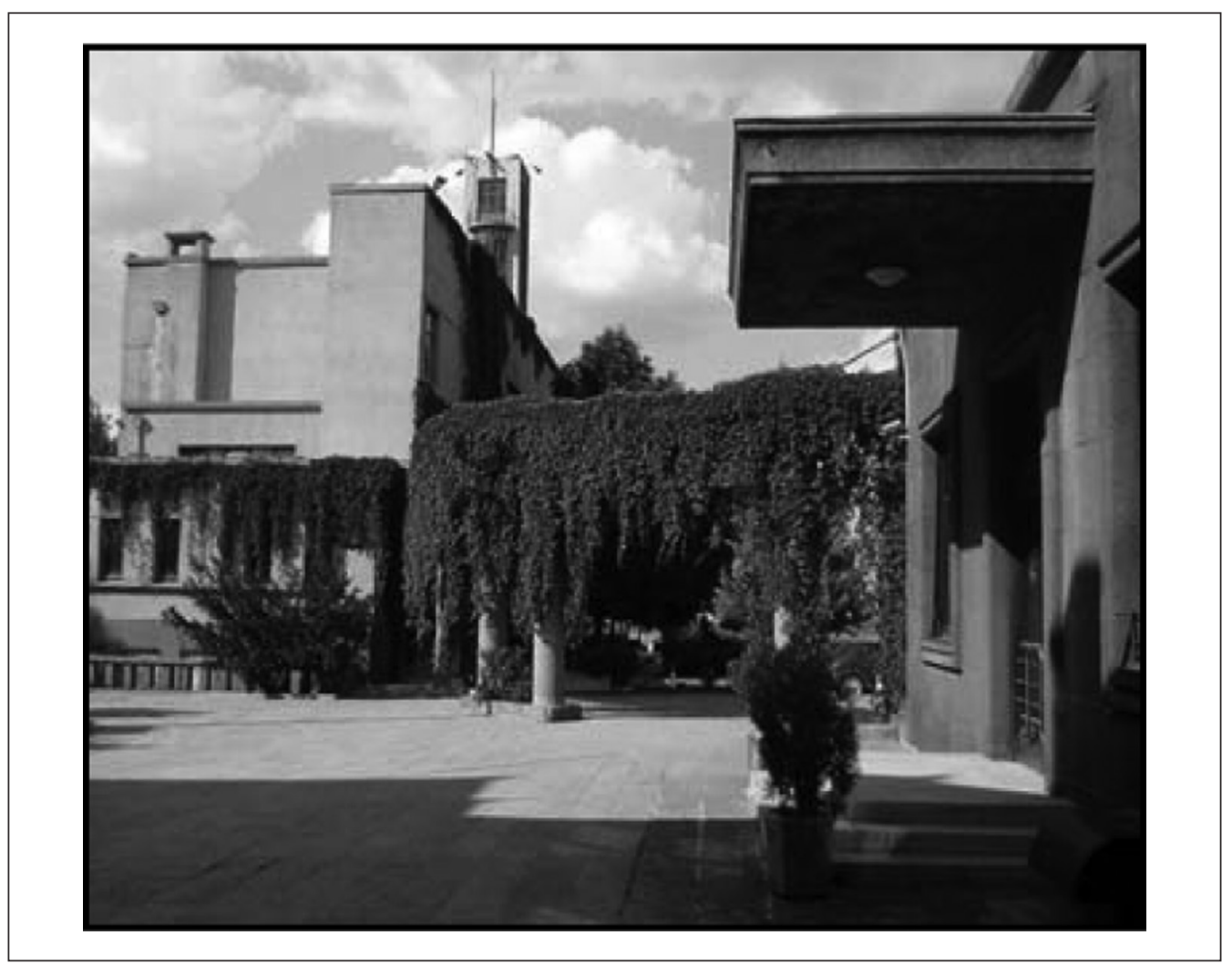

Figure 10. Joint between the station building and the casino building. Source: Photograph taken by Segah Sak.

no columns in the entrance hall; the clearance being provided by six steel trusses twenty-three meters in length. ${ }^{62}$ The finishing material of the stairs, floor, the lower parts of the walls in the hall, and the platform is marble. The significant ticket counters, on the both sides of the main hall, are also marble. There are buffets that serve the hall and the platforms (see Figure 12). Architectural historian Yavuz explains that this hall gives the feeling of a simple but striking large interior space lit by the long, wide windows. ${ }^{63}$

The ancillary volumes on both sides of the entrance hall consist of three, two, and single floors, respectively. The public spaces and service areas such as waiting halls, the restaurant with terrace, the security and post offices, the baggage room, and the toilets are on the ground floor. The phone department, the control room, the boiler room, and the kitchen of the restaurant are also located on the ground floor. ${ }^{64}$ On the upper floors, there are flats for the personnel and their families. The stairs leading to the residences are located in the circular blocks on both sides of the symmetrical main hall.

The allocation of spaces and the integration of materials used provide continuity both as a visual quality and for the activities provided. The building is considered to have a special place in the architectural history of the early republican period based on its elaborate construction and careful detailing. Consequently, it is possible to claim that the building, by its physical entity and the activities and services it provided, was an indispensable component in the setting. 


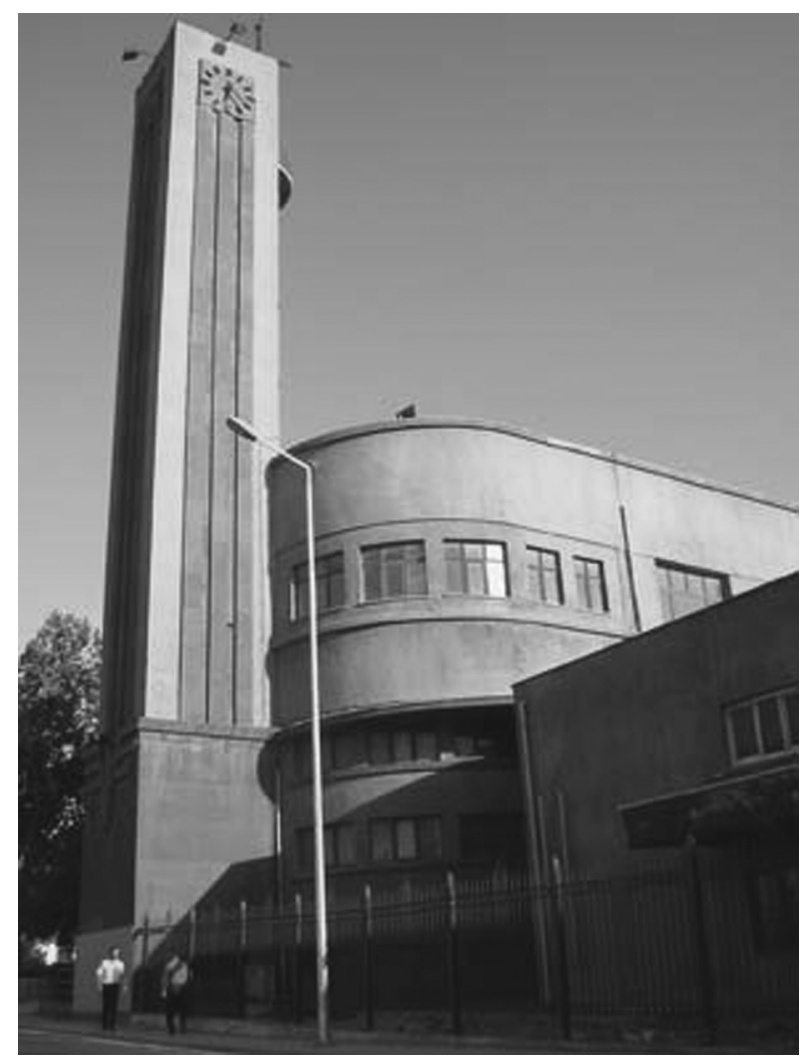

Figure I I. The casino building and the clock tower. Source: Photograph taken by Segah Sak.

\section{The Symbolic Value of the Train Station}

The station has a strong symbolic value first of all because of its role as the gate of the city. Being a gate makes the station valuable for both the arriving visitors and the departing passengers, as it provides the first and the last impressions of the city. ${ }^{65}$ Consequently, it can be argued that, having an immediate influence on the perception of the city, Ankara Train Station itself acted as a mediator for the formation of the image of the new capital. According to Şevket, the train station, meeting the arriving passengers with its stability, beauty, and cleanness as a symbol of new Turkey, constituted a scene that rested the eyes of the passengers and prepared their imagination for what they would experience in the city. ${ }^{66}$

Moments ago, we were in the midst of the desert; after we exit from the train station we found ourselves in the liveliness of a big, modern city with its wide asphalt paved roads, in contrast with the narrow, twisted streets of Istanbul. ${ }^{67}$

The importance of being a gate for the city can also be argued upon the theory of sociologist Simmel on the vitality of doors in separating and uniting places. ${ }^{68}$ According to him, two spaces 


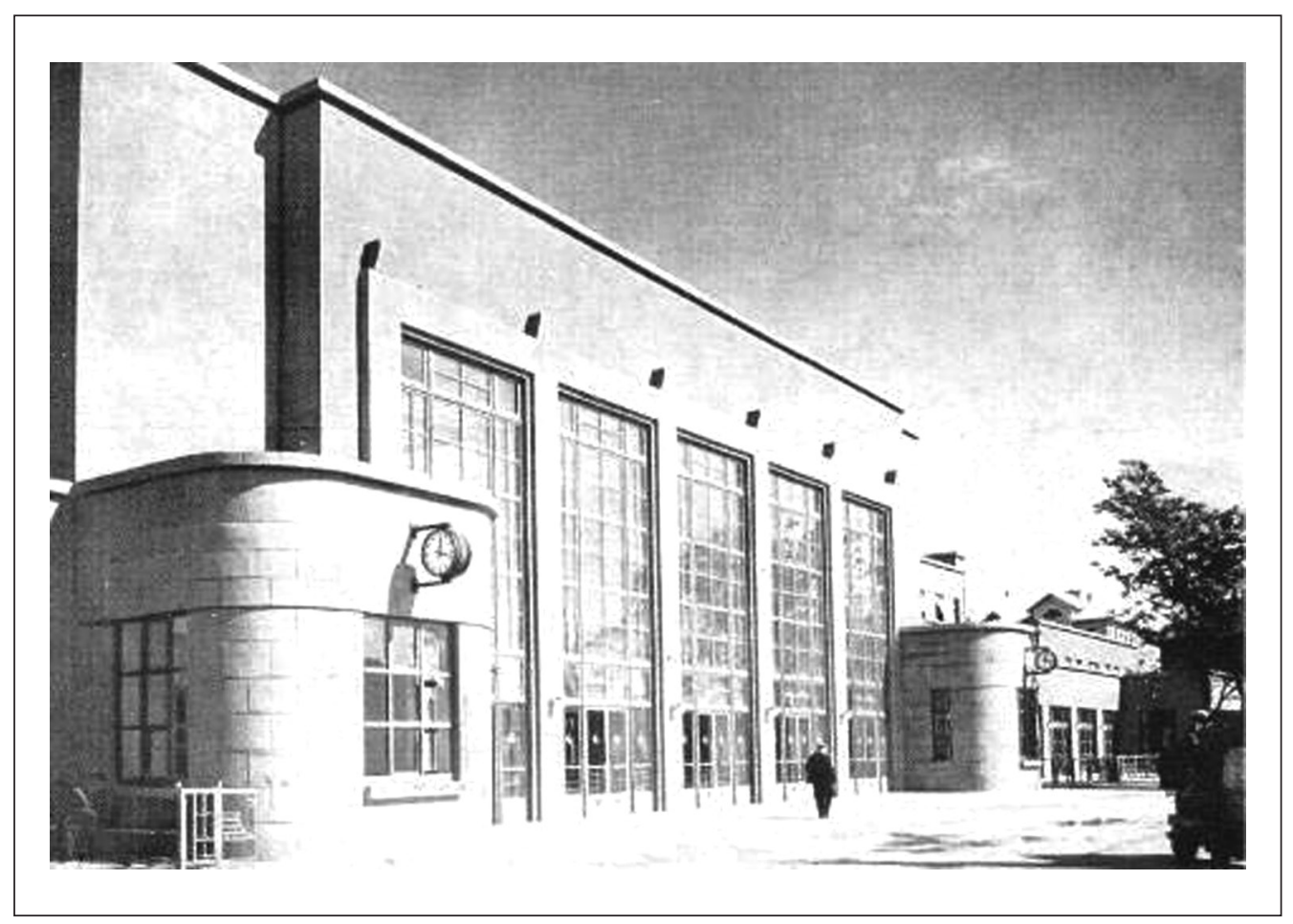

Figure 12. Entrance from the platforms.

SOURCE:T.C.D.D., Fotoğraflarla Yeni Ankara Garı [New Ankara Train Station in photos] (Ankara:T.C.D.D. Genel Müdürlüğü, 2006, original work published in 1937), 53.

cannot be perceived to be separate unless there is a door that connects them. What helps to consider and evaluate a place as a separate entity is its separation from and connection to the others. Station building, in this context, serves as a descriptive urban element since it means both separation and connection for the city. Moreover, in Ankara, practical and symbolic value of the station as an urban space of encounter informed the image formation of the capital. It can be interpreted that without the existence of the station and the mediation by its entity, the perception and the image of the capital would not be completed.

This case was legitimated in the statements objecting to Ankara being the capital. Güvenç interpreted an article of Samih Saim published in 1933 in Mimar (the most popular and influential architectural journal of the period) as that the author considered Haydarpaşa Station (the central station of Istanbul) as the gate to Ankara, thus to the country. ${ }^{69}$ Güvenç believed that this was a sign of the ongoing implicit conflict between the architects of Ankara and Istanbul. ${ }^{70}$ That was because the existence of Ankara was claimed to be essentially dependent on Istanbul and it is argued that the citizens of Istanbul created Ankara. ${ }^{71}$ The mentioned statements objecting to Ankara being the capital legitimate the discussion on the indispensability of the train station as the gate of the city. The argument here is that the train station defined the capital as a unique entity and consequently gave the capital the chance to define the people coming from Istanbul as "the citizens of Ankara." 72 Yet, there were people of Istanbul who could not be convinced by Ankara, such as Yahya Kemal Beyatl1, a famous Turkish poet, who stated that the best thing about Ankara was returning to Istanbul. Even in such case, it is possible to define the train station as the gate from which they could exit Ankara and enter their beloved Istanbul. 


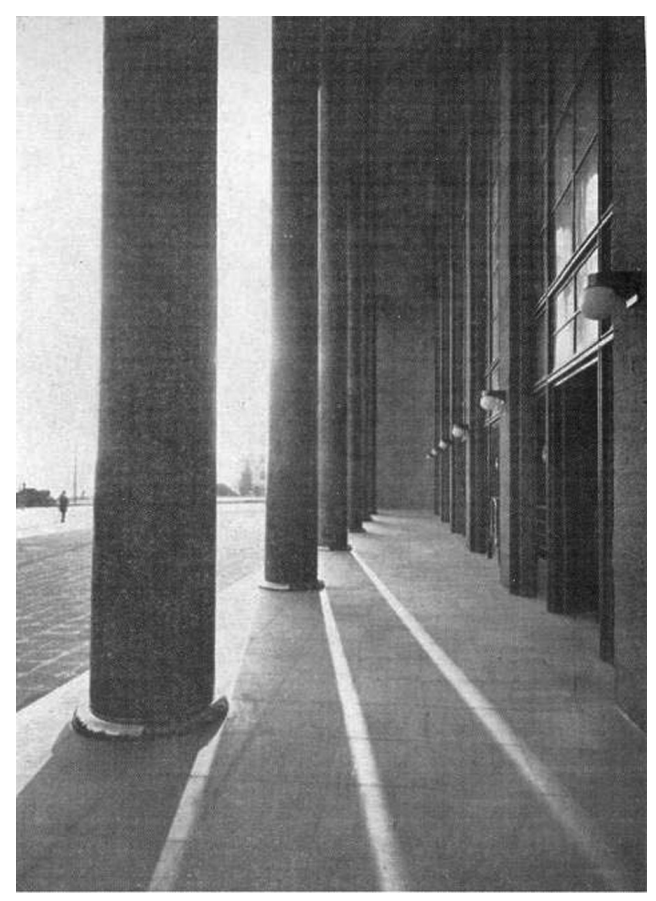

Figure 13. Entrance from the city.

SOURCE:T.C.D.D., Fotoğraflarla Yeni Ankara Garı [New Ankara Train Station in photos] (Ankara:T.C.D.D. Genel Müdürlüğü, 2006, original work published in 1937), 5 I.

Consequently, it is reasonable to state that the station was indeed a symbol of the existence of the capital and the new state.

Moreover, depending on the assumption that buildings represent their era and help to understand the socioeconomical and political developments in the history of a country, ${ }^{73}$ it can be argued that the train station with its particular function and structural qualities symbolized the developments achieved. ${ }^{74}$ First, the modern and rational design of the station symbolized the modernity of the city and the state. New forms of the modern architecture were named as "cubic" at the time. "Modern" was visually distinguished from "traditional" by means of the clear-cut geometrical forms. The rational "cubic style" of the station building discarded any kind of traditional expression, thus, it was accepted as a representative of modernity, basically depending on the formal criteria. Kutay claimed that the new Ankara Train Station was built as the first and last ring of the chain of the thought: the republic had built one of the most modern cities of the world on this piece of desert. ${ }^{75}$ In parallel, Yiğit states that the station had the usual dignity, temperance, and distance, expressing the identity of being the capital. ${ }^{76}$

Secondly, the building symbolized the power of the state by developing railways. ${ }^{77}$ A special emphasis was placed on construction of railroads in the early years of the republic. This effort was expressed even in the anthem written by Çağlar and Çamlıbel in 1933 to celebrate the tenth anniversary of the republic: "We adorned our whole homeland by railroads." The railroads represented communication and transportation, and they were a precondition of contemporary 


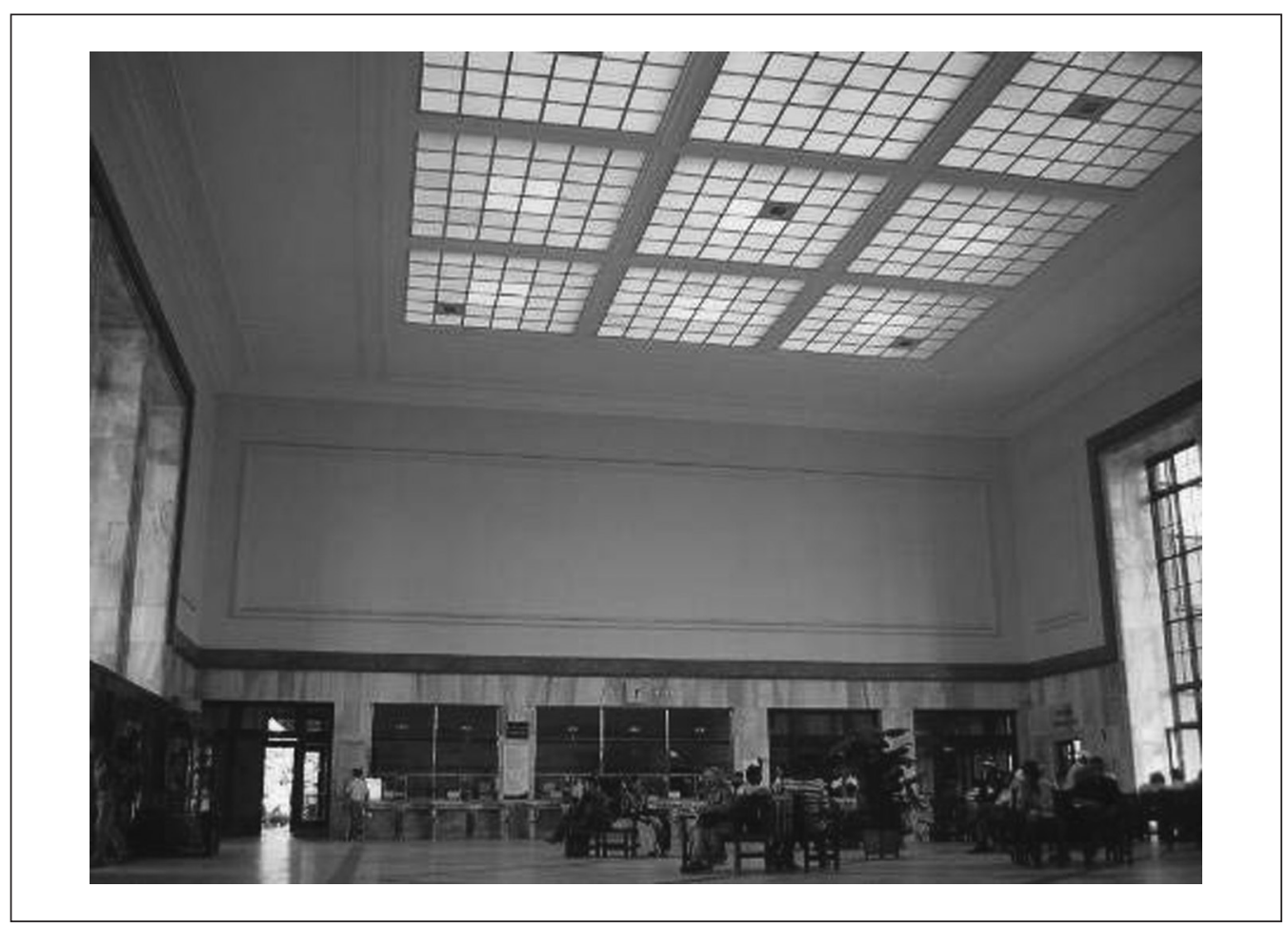

Figure 14. The main hall.

Source: Photograph taken by Segah Sak

civilizations. According to Uluğ, railroads were the primary instruments of the republic, which he specifically defined as freedom, national unity and integrity, civilization, construction, and development. ${ }^{78}$ The station was considered proof of success of the republic: the new and "magnificent" train station was such certification of success, perfectness felt so natural in it. ${ }^{79}$ This is the reason for that the newspapers of the period to place special emphasis on the construction, opening and the use of the station (see Figures 16 and 17).

\section{Experience of the Train Station}

The capital Ankara was constituted of only a few public places in the early years of the republic. Nonetheless, they actually were the instruments employed by the state to generate the idea of capital as a representation of the republic. Thus, the public spaces were designed to be the setting and the mediator of a collective contemporary experience.

Sargin explains that the discourse about, and the forms of production of urban spaces, in the early years of the republic, were extensions of civil publicness. Specifically, they were coeval representations of the discourses of official publicness. ${ }^{80}$ It can be claimed that the publicness of urban spaces were, to a degree, restricted by the state. Öymen mentions how the governor of the capital, Nevzat Tandoğan, interfered not only with people who did not obey the clothing reform, but also those dressed unpleasantly. ${ }^{81}$ Consequently, the public places of the capital had filtering mechanisms of their own depending sometimes on their function; or economical, social, cultural, aspects; or, for some reason, authoritarian restrictions. 


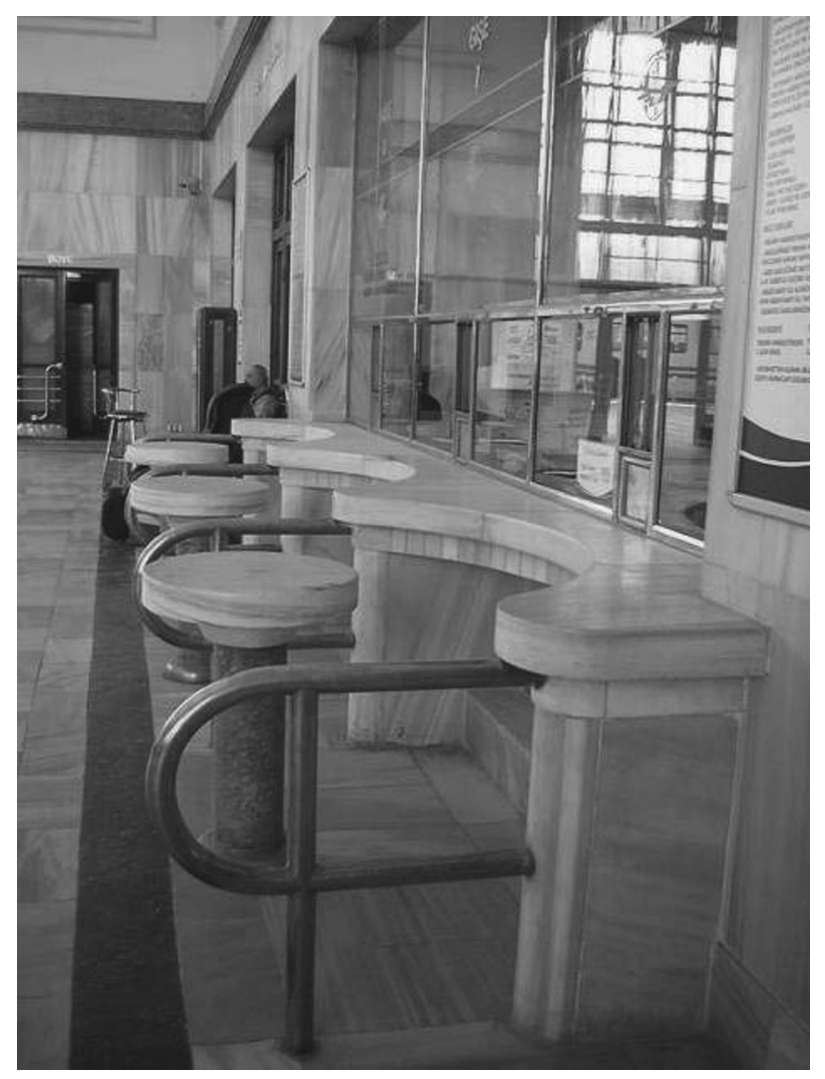

Figure I5. The ticket counters.

Source: Photograph taken by Segah Sak

Nevertheless, the train station formed an exceptional example of publicness among the other public spaces of the early republican capital. What makes it a genuinely public place is that "people at large need no legitimate purpose to enter and to use." $" 22$ This quality may be considered to be the function of the station: it was a place where people went for a daily common purpose regardless of political standing, economic or social status, or cultural conformation. Just as Graham explains, public buildings serve anyone and everyone and can properly be called public architecture when their very features make this evident. ${ }^{83} \mathrm{We}$ can actually deduce this publicness of the Ankara Train Station from the observation by Şevket:

As soon as the first whistle was heard, voices arose.

People who bid farewell to the passengers of third class coaches: God bless you! (Allah selamet versin!)

To the passengers of second class coaches: Good bye! (güle güle!)

To the first-class passengers: Bon voyage! $!^{84}$ 


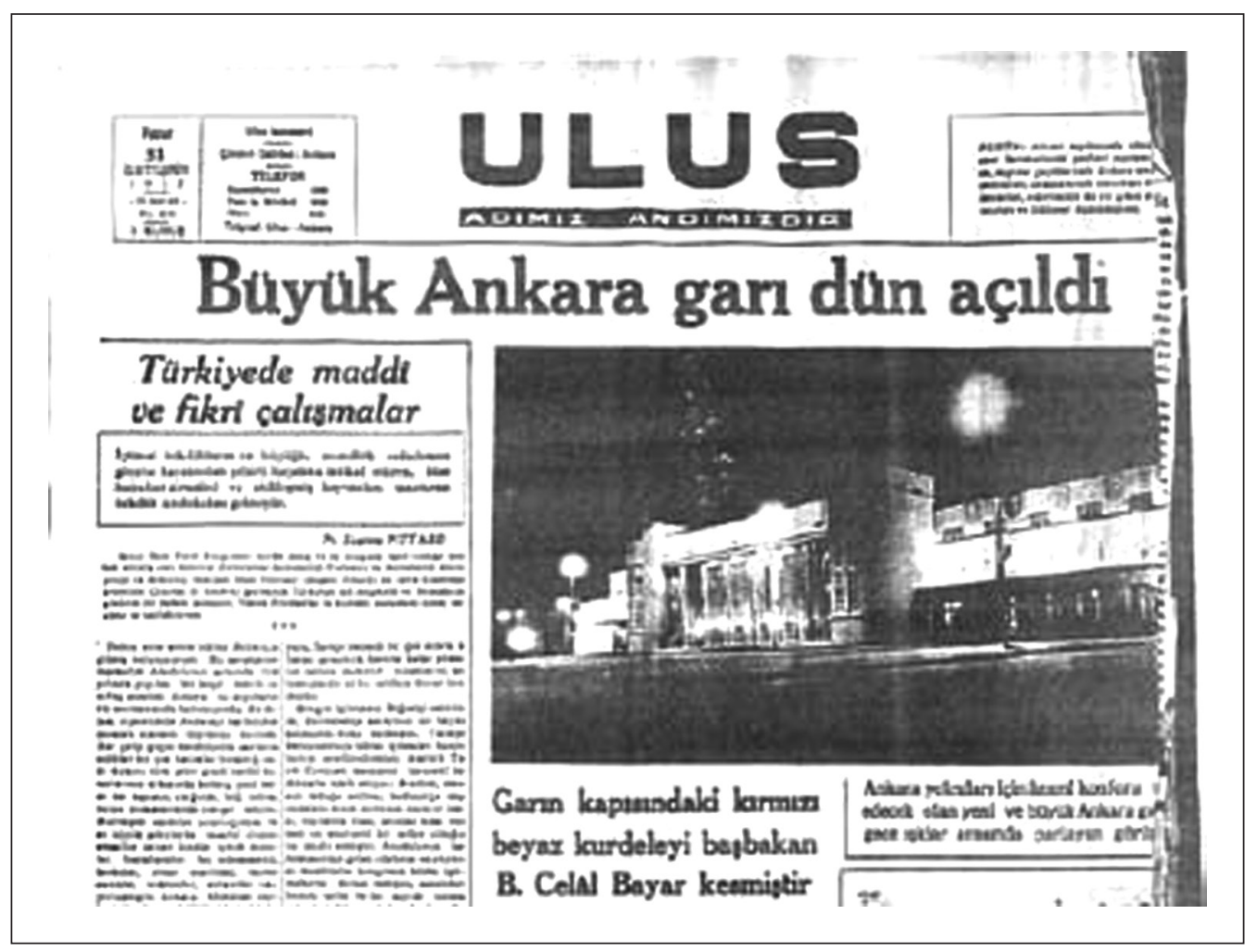

Figure I 6. "The Grand Ankara Train Station Opened Yesterday." Source: Ulus, October 31, 1937, I.

The station thus afforded the experiences not only to a particular group, but rather, to people from different groups. More explicitly, the city images formed by modest citizens of the capital who, for instance, lived within the citadel, may not comprise Ankara Palace observed only from a distance, but it is likely that the train station influenced their image of Ankara by a stimulus that they were directly exposed to.

Batuman defines public spaces as places where personal experiences are socialized and where daily life and political discourse intertwine. ${ }^{85} \mathrm{He}$ also adds that public spaces determine the scope of the discourse that transform social images into political meanings. This may be linked to the public's consciousness of its environment. The consequence of actualizing the interaction between the public and the setting results in a rise of consciousness. This consciousness may be interpreted as a consciousness of the meaning of space and time, dependent on power struggle. Within an urban space, members of society determine their socio-political standing that channel their meaning attachment. For passengers of second- and third-class coaches, considering the majority of existing urban public spaces and the aforementioned circumstances, the station presumably meant social existence in the public space. Moreover, any sympathizer of the revolution and westernization project would certainly appreciate hierarchical segregation considering they share a common urban place with dignitary. On the other hand, for members of the so-called high class (for the politicians and bureaucrats), the public station did provide the opportunity to witness real-life occurrences to build an image of the city. 


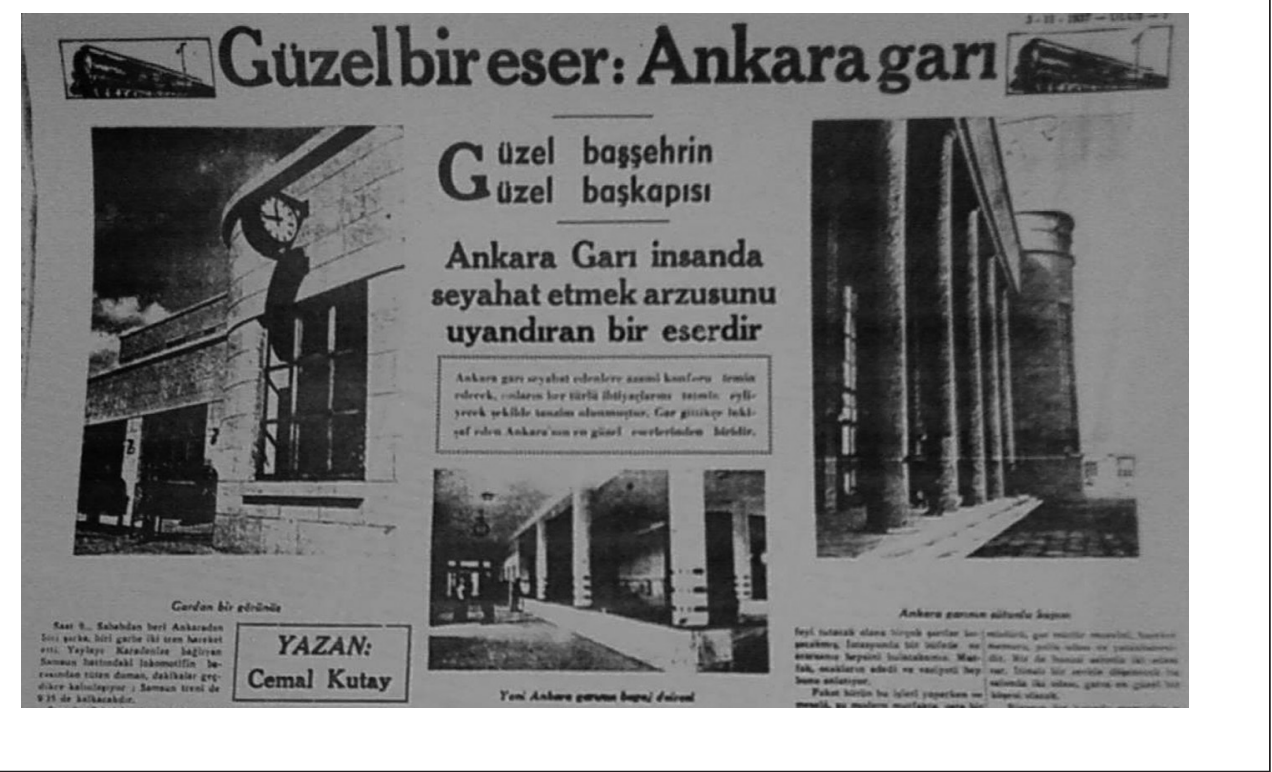

Figure I 7. "A Beautiful Creation: Ankara Train Station-The Beautiful Gate of the Beautiful Capital." Source: Ulus, November 2, 1937, 7.

Consciousness may also be discussed as awareness of and familiarity with the experiences within an urban space. This type of consciousness is a result of an interaction that was assured by the train station. New social practices and sensibilities were introduced to the public at large. Kutay, presumably aware of this potential of interaction, expressed his expectation of a more civilized behavior in the station and in all other public spaces: "if we care more about walking on the right, there would not be people, angry to have run into each other, even at the busiest times." ${ }^{86}$ Furthermore, the Station Casino accommodated new activities and services. Bayraktar states that this casino was as good as similars in Europe, with excellent food and service offered. ${ }^{87}$ Also, the casino introduced an exclusive entertainment culture to the citizens. And, the privilege of this experience was shared by the elites and the ordinary public. Thus, its implementation cultivated the interaction between all the members of the public.

In any case, people attached their meaning of the station within the context or limits of its publicness. According to Batuman, during the construction of publicness, places play a role not only as "environments" but also as "representative objects." 88 Thus, the dynamics of the public of the capital could be observed within the station.

Beyond seeing it as a symbol of development, the state's regard for railroads overlapped the appreciation by the citizens. As was stated by Uluğ, especially in a country in which transportation was provided mainly by tiresome wagons, the value of the railroads was much more. ${ }^{89}$ Turkish villagers referred to railroads as "uniters and healers of yearning" 90 because railroads had decreased the distances of and hours spent on traveling. Under the circumstances of the era, transportation and communication, provided by railroads, was vital for a civilized country. Şevket mentions this vitality depicting Ankara as the heart and the railroads as the veins of the country. ${ }^{91}$ According to him, the train station assured the beating of this heart to distribute its blood, namely, the trains. 
The particular significance of the train station depended heavily on nationalist discourse. This train station was the first urban artifact built by a Turkish architect, a Turkish engineer, and a Turkish entrepreneur. Although representing a universal style, it was essentially a product of the Turkish people. Şevket expressed his admiration and pride of this fact in describing the train station as a majestic bronze sculpture in the middle of the desert, by Turkish intelligence. ${ }^{92}$ The splendid rise of such a stable, beautiful, and clean building, as Şevket characterized it, ${ }^{93}$ must have impressed any citizen of the city, and as it was mentioned before, this pride must have influenced not only their image of the city but also their self-image in reflection. After all, the train station provided them the confidence of meeting any foreigner in the train station. This confidence pertained not only to the architectural and symbolic being of the train station, but the contemporary spaces and experiences it provided also empowered the people "to be more courageous and hopeful." 94

The public in question had recently recovered after the harsh conditions of consecutive wars. The train station was something new for the citizens, ${ }^{95}$ and it was a promise of future developments to come. The station introduced a clean and luxurious environment. It was such salient quality that Baydar stated: the particular quality of the new building was its cleanness and largeness. ${ }^{96}$ Kutay cautioned that citizens would hesitate to enter the hall with their dirty shoes, ${ }^{97}$ while Sevket felt that the clean marble floor gave him a sense of pompous freshness. ${ }^{98}$ Moreover, Şevket was impressed by the clean white suits worn by the waiters in the casino. ${ }^{99}$ Cleanliness was likely to have been associated with a high civilization level.

Approaching the station in luxurious private automobiles, ${ }^{100}$ entering the hall in which the humidity was in the optimum level, ${ }^{101}$ experiencing the exclusive services provided, after a period of struggle, all contributed to the sense of comfort. Even comfortable seating provided in the waiting halls of the station was considered by the public as a luxury. Anything that provided people with joy of comfortable sitting and living was sacred to them. ${ }^{102}$ The hope in the future and the joy of the present that the station and its setting assured led to the formation of a positive image of the city.

In the early years of the railroads, the arrival of trains counted as important events in Ankara. ${ }^{103}$ After its construction, the Ankara Train Station, offering a modern, civilized, comfortable, and clean environment, continued to accommodate important events. Everything was designed to an envisioned perfection. ${ }^{104}$ The novelty of the station kept the citizens from rushing home ${ }^{105}$ by providing them activities to keep them inside for a couple of hours to spend joyful times. ${ }^{106}$ Thus, it became a place used not only for a particular activity, but rather as an urban public space in which the public created its own activities. Citizens who witnessed the early times of the republic recalled that they went to the train station in their best clothes, sometimes just to spend time walking for hours along the platforms awaiting trains from other cities, especially Istanbul. If the station had not ensured the joy of being in the new capital, it must have ensured at least a comfortable and luxurious departure as an exiting door. Eventually, the experience of the train station triggered attachment of people to both, this specific public space and the city. The building constituted a significant setting for the collective memories of the early republican period.

\section{Conclusion}

Early republican Ankara, with its image dependent on a certain ideology, constitutes a significant case study of the concept of city image. Ankara is significant because it proves that this concept can be studied and traced through various periods, and because it constitutes an example of cities which have images created not only by economic concerns. ${ }^{107}$

Ankara, becoming the capital of the Turkish republic in 1923, was accepted to be the center of and a tool for the revolutionary act of the new nation-state - not only a city but also as an 
image of the new republic being created. Between 1923 and 1950, the city and its image were formed simultaneously. The intention was to build a modern and westernized capital to shape the social, political, economical, and cultural structure to the level of contemporary civilizations and to create an image to convince both the public and the outer world about the determination to leave the imperial and Islamic Ottoman in past and to accept a modern, westernized, and secular culture. In this manner, the ideological discourse of the state was revealed and imposed in the urban public spaces.

The emphasis on the train station stems from the claim that the building type had an exclusive significance for the period in which the city and its image were formed. The setting that it was located constituted an indispensable article of the structure of the city orienting the spatial syntax. By its architecture and activities it accommodated, it contributed to a "modern" and "westernized" identity of the city. And importantly, this modern building was nurtured, invested in, designed, and constructed by Turkish professionals different than its contemporaries, which were the products of mostly German-speaking architects. So, the Turkish identity was signified in the formation of the building. Yet, it should be mentioned that in terms of form, it could not distance itself from the German influence: the massive, symmetrical buildings characteristics of German modernism.

The construction and experience of the train station and its setting implied some meanings for the new capital and its citizens. First, the station as the gate to the city acted as an immediate stimulus for creating a perception of the city and mediating the creation of the image. As a building of prestige, it symbolized the city and the state. Because railroads were products and instruments of the modern world, the development of railroads was considered to be reflecting the state's progressive course toward a modern and civilized country. For that reason, Ankara Train Station, as well as many other examples built in this country, is considered to be one of the first examples of modern architecture.

The publicness of the train station was incontrovertible expression of the period in question. Conveying the symbols and intentions was a further contribution by the train station to the image of the city. In addition, publicness encouraged people to attach meanings to their built environment and raised their consciousness to take their position within the society. People went to the station not always for travel, but frequently just to socialize dressed in their finest. In time, the station provided the public with services and spaces for comfortable, joyful, and civilized urban experiences.

The city of Ankara has witnessed many changes through time, mainly in terms of demography, society, and spatiality. The capital now is not the city that was designed during the early years of the republic. The activities and the spaces displayed a considerable differentiation, starting in the 1950s. Today, it is even more complicated to follow the shifts occurring in the urban space, due to unsystematic development of the city. Although the physical fabric of the city lost its coherence, the meaning of the city, conveyed in the early years of the republic, is still preserved. This is because the city and its image were dependent fundamentally on an ideology. So, as long as the ideology exists, the city will maintain its presence, if not in the manner of spatiality that was intended, but then, as a mental image of the early republican Ankara.

\section{Acknowledgment}

The authors would like to thank Mr. Herbert Bassler, who contributed to the improvement of the language of this article by his rigorous revisions.

\section{Declaration of Conflicting Interests}

The author(s) declared no potential conflicts of interest with respect to the research, authorship, and/or publication of this article.

\section{Funding}

The author(s) received no financial support for the research, authorship, and/or publication of this article. 


\section{Notes}

1. Wim P. Blockmans, "Reshaping Cities: The Staging of Political Transformation," Journal of Urban History 30, no. 1 (2003), 19.

2. Ibid., 9

3. For a more detailed information on the coeval formation of Ankara and its image, see Segah Sak, "Formation of the City Image: The Role of the Train Station in the Image Formation Process of Ankara" (Unpublished master's thesis, Ankara: Bilkent University, 2008) from which this paper is derived from.

4. Kevin Lynch, The Image of the City (Cambridge: The Technology Press \& Harvard University Press, 1960), 2-3.

5. Ibid., 8 .

6. Ibid., 9

7. Jack L. Nasar, The Evaluative Image of the City (Thousand Oaks: Sage Publications, 1998).

8. Ibid., 3

9. M. Christine Boyer, The City of Collective Memory: Its Historical Imagery and Architectural Entertainments (Cambridge; London: MIT Press, 1996), 32.

10. Ibid., 46

11. For example, see Teodoro Luque-Martínez, Salvador Del Barrio-García, José Ángel Ibáñez-Zapata, and Miguel Ángel Rodríguez Molina, "Modeling a City's Image: The case of Granada," Cities 24, no. 5 (2007), 338; Philip Kotler, Donald H. Haider, and Irving Rein, Marketing Places: Attracting Investment, Industry, and Tourism to Cities, States, and Nations (New York: Free Press, 1993), 141.

12. Boyer, The City of Collective Memory, 30; Aldo Rossi, The Architecture of the City, translated by Diane Ghirardo and Joan Ockman (Cambridge, MA: MIT Press, 1992), 21. Boyer defines the city as "the collective expression of architecture". In parallel, Rossi explains that "architecture came into being along with the first traces of the city; it is deeply rooted in the formation of civilization and is a permanent, universal, and necessary artifact."

13. Elizabeth Blackmar, "The Urban Landscape," Journal of Architectural Education 30, no. 1 (1976), 13.

14. Lynch, The Image of the City, 110 .

15. Ibid., 72,73 .

16. Asuman Türkün Erendil and Zuhal Ulusoy, "Reinvention of Tradition as an Urban Image: The Case of Ankara Citadel," Environment and Planning B: Planning and Design 29, no. 5 (2002), 657.

17. Boyut Yayın Grubu, Ankara 1910-2003 (Istanbul: Boyut Yayınları, 2003), 7.

18. İlber Ortayl1, "19. Yüzyılda Ankara" [Ankara in the 19th Century], in Enis Batur, ed., Ankara Ankara (Istanbul: Yapı Kredi Yayınları, 1994), 119.

19. Sevgi Aktüre, "17. ve 18. Yüzyıllarda Ankara" [Ankara in the 17th and 18th Centuries], in Enis Batur, ed., Ankara Ankara (Istanbul: Yap1 Kredi Yayınları, 1994), 105.

20. Grubu, Ankara 1910-2003, 7.

21. After the First World War, the country was divided into separate parts by foreign power to claim dominance over those regions.

22. Ortayl1, "19. Yüzyılda Ankara", 119.

23. Erendil and Ulusoy, "Reinvention of Tradition," 657

24. Mehmet Ali Kılıçbay, "Homo Politicus Ancyrensis," in Enis Batur, ed., Ankara Ankara (Istanbul: Yap1 Kredi Yayınları, 1994), 141.

25. Erendil and Ulusoy, "Reinvention of Tradition," 657.

26. The War of Independence was against the foreign powers and the governance of Ottoman Empire itself.

27. İlhan Tekeli, “Ankara'nın Başkentlik Kararının Ülkesel Mekan Organizasyonu ve Toplumsal Yapıya Etkileri Bakımından Genel Bir Değerlendirilmesi” [A General Assessment of the Decision of Determining Ankara as the Capital in Means of Its Effects on the National Space Allocation and on the Social Structure], in Enis Batur, ed., Ankara Ankara (Istanbul: Yap1 Kredi Yayınları, 1994), 147. 
28. Kılıçbay, "Homo Politicus Ancyrensis," 141.

29. Ayhan Akman, "Ambiguities of Modernist Nationalism: Architectural Culture and Nation-Building in Early Republican Turkey,” Turkish Studies 5, no. 3 (2004), 110.

30. Neşe Yeşilkaya, "Ankara: Modernliğin Temsili” [Ankara: Representation of Modernity], TMMOB Mimarlar Odası Ankara Şubesi Bülteni 31 (2005), 14.

31. Zeynep Uludağ, "Geçen Modern Zamanların Ardından Kaybolan Anlamlar" [Lost Meanings after Former Modern Times], TMMOB Mimarlar Odası Ankara Şubesi Bülteni 31 (2005), 30.

32. Rossi, Architecture of the City, 21.

33. Sibel Bozdoğan, Modernism and Nation Building: Turkish Architectural Culture in the Early Republic (Seattle \& London: University of Washington Press, 2001), 10.

34. Erendil and Ulusoy, "Reinvention of Tradition," 657.

35. Nuray Bayraktar, "Modern Ankara'da Yaşama ve Mekana Dair" [About life and place in modern Ankara], TMMOB Mimarlar Odası Ankara Şubesi Bülteni 31 (2005), 23.

36. Bozdoğan, Modernism and Nation Building, 6; Elvan Altan Ergut, "Ankara 'Bankalar Caddesi' ve Ötesi” [Ankara Ministries Road and beyond], TMMOB Mimarlar Odası Ankara Şubesi Bülteni 31 (2005), 28.

37. Bozdoğan, Modernism and Nation Building, 6.

38. Ibid., 11.

39. Metin Sözen, Cumhuriyet Dönemi Türk Mimarlğg [Turkish architecture in republican period] (Istanbul: Türkiye İş Bankası Kültür Yayınları, 1984), 40-1.

40. Bozdoğan, Modernism and Nation Building, 11.

41. Ali Cengizkan, Ankara'nın ilk planı: 1924-25 Lörcher planı [The first Plan of Ankara: 1924-25 Lörcher Plan]. (Ankara: Ankara Enstitüsü Vakfi, 2004), 35.

42. Ibid., 39.

43. Bayraktar, "Modern Ankara'da Yaşama ve Mekana Dair”, 23.

44. Yıldırım Yavuz and Süha Özkan, "Finding A National Idiom: The First National Style," in Renata Holod, Ahmet Evin, and Süha Özkan, eds., Modern Turkish Architecture (Philadelphia: University of Pennsylvania Press, 1984), 24.

45. Ergut, "Ankara 'Bankalar Caddesi’ ve Ötesi,” 28.

46. Gönül Tankut, Bir Başkentin İmari: Ankara, 1929-1939 [Reconstruction of a Capital: Ankara, 1929-1939] (Ankara: Orta Doğu Teknik Üniversitesi, 1990), 56.

47. Ibid., 56 .

48. Bozdoğan, Modernism and Nation Building, 75.

49. Lynch, Image of the City, 1.

50. Yıldırım Yavuz, "1923-1940 Arası Ankara'da Mimari” [Architecture in Ankara Between 1923 - 1940], in Enis Batur, eds., Ankara Ankara (Istanbul: Yapı Kredi Yayınları, 1994), 202.

51. Yakup Kadri Karaosmanoğlu, Ankara (Istanbul: İletişim Yayınları, 1991), 121.

52. Bozdoğan, Modernism and Nation Building, 75.

53. Uludağ, "Geçen Modern Zamanların Ardından Kaybolan Anlamlar," 31.

54. Ergut, "Ankara 'Bankalar Caddesi' ve Ötesi," 28.

55. Brian Edwards, The Modern Station: New Approaches to Railway Architecture (London \& New York: E FN SPON, 1998), 13.

56. Lynch, Image of the City, 74.

57. Kemal Zeki Gencosman, "Bizim Ankaralı hemşeriler artık sayfiyeden dönüyorlar" [Our Fellow Citizens Are Now Returning from Summer Houses], Ulus, October 5, 1938, 7.

58. Claude Farrère, Ankaralı Dört Hanım [Four ladies of Ankara], translated by Kriton Dinçmen, (Istanbul: Arion Yayınevi, 2003), 18.

59. T.M.M.O.B., Bina Kimlikleri [Identities of Buildings] (Ankara: TMMOB Mimarlar Odası Ankara Şubesi Yayınları, 2005), n.p. 
60. T.M.M.O.B., n.p.; T.C.D.D., Fotoğraflarla Yeni Ankara Garı [New Ankara Train Station in photos] (Ankara: T.C.D.D. Genel Müdürlüğü, 2006, original work published in 1937), 11.

61. Yavuz, "1923-1940 Aras1 Ankara'da Mimari," 208.

62. T.C.D.D., Fotoğraflarla Yeni Ankara Garı, 11.

63. Yavuz, "1923-1940 Aras1 Ankara'da Mimari," 208.

64. Cemal Kutay, "Güzel bir eser: Ankara Gar1," Ulus, November 3, 1937, 7.

65. Ibid., 7.

66. Ertuğrul Şevket, “Avrupa'nın En Modern İstasyonu” [The Most Modern Station of Europe], Yedigün 332 (1939), 15.

67. Henri Liebrecht, "1937 Türkiyesi" [Turkey in 1937], Ulus, August 8, 1937, 4.

68. Georg Simmel, "Bridge and Door," in David Frisby and Mike Featherstone, eds., Simmel on Culture: Selected Writings (Thousand Oaks, CA: Sage, 1997), 172.

69. Kenan Güvenç, "Örtük Bir Çatışma Şüphesi” [Doubt of an Implicit Conflict], in Enis Batur, ed., Ankara Ankara (Istanbul: Yap1 Kredi Yayınları, 1994), 219.

70. Ibid.

71. Kilıçbay, "Homo Politicus Ancyrensis," 141.

72. Ibid., 141.

73. Yavuz, "1923-1940 Aras1 Ankara'da Mimari," 202.

74. Zeynep Uludağ, "Ankara'da Cumhuriyetin Modern Kent Peyzajının Sembolik Değerleri: Ankara Garı ve Çevresi" [The Symbolic Values of the Republic's Urban Landscape in Ankara: Ankara Train Station and Its Environment], in Emin Onat and Sercan Özgencil Yıldırım, eds., Göstergebilim Tartıșmaları (Istanbul: Multilingual, 2001), 170.

75. Kutay, "Güzel bir eser," 7 .

76. Şükran Yiğit, Ankara, Mon Amour! (Istanbul: İletişim Yayınları, 2003), 163.

77. Yavuz, "1923-1940 Aras1 Ankara'da Mimari," 208.

78. Naşit Uluğ, "Demiryolu Politikası" [Railroad Policy], Ulus, December 12, 1938, 4.

79. Kutay, "Güzel bir eser," 7 .

80. Güven Arif Sargın, "Kamu, Kent ve Polytika" [Public, City and Politics], in Güven Arif Sargın, eds., Ankara'nın Kamusal Yüzleri (Istanbul: İletişim Yayınları, 2002), 34.

81. Altan Öymen, Bir Dönem Bir Çocuk [A Period, a Child] (Istanbul: Doğan Kitapçılık, 2002), 81.

82. Gordon Graham, "Can There Be Public Architecture," The Journal of Aesthetics and Art Criticism 64, no. 2 (2006), 248.

83. Ibid., 248 .

84. Şevket, “Avrupa'nın En Modern İstasyonu,” 16.

85. Bülent Batuman, "Erken Cumhuriyet Ankarası" [Ankara of the Early Republic], TMMOB Mimarlar Odası Ankara Şubesi Bülteni 31 (2005), 13.

86. Kutay, "Güzel bir eser," 7 .

87. Bayraktar, "Modern Ankara'da Yaşama ve Mekana Dair," 26.

88. Batuman, "Erken Cumhuriyet Ankarası," 13.

89. Uluğ, "Demiryolu Politikası," 4.

90. Ibid.

91. Şevket, “Avrupa'nın En Modern İstasyonu,” 15.

92. Ibid.

93. Ibid

94. Kutay, "Güzel bir eser," 7 .

95. Ibid.

96. Nasuhi Baydar, "Bir ay içinde tamamen değişiveren Ankara," [Ankara that Has Changed Suddenly in a Month], Ulus, November 5, 1937, 2.

97. Kutay, "Güzel bir eser," 7 . 
98. Şevket, “Avrupa'nın En Modern İstasyonu,” 15.

99. Ibid., 16.

100. Ibid., 15.

101. Kutay, "Güzel bir eser," 7.

102. Ibid.

103. Grace Ellison, Ankara'da bir Ingiliz Kadını, translated by Osman Olcay (Istanbul: Bilgi Yayınevi, 1999), 150 .

104. Kutay, "Güzel bir eser," 7.

105. Baydar, "Bir ay içinde tamamen değişiveren Ankara," 2.

106. Kutay, "Güzel bir eser," 7.

107. The majority of the recent studies on city image are conducted in the scope of tourism and "place promotion" and concentrates on "destination image." For some examples of works on city image in the scope of tourism, see Kotler et al., Marketing Places; John R. Gold and Stephen V. Ward, Place Promotion: The Use of Publicity and Marketing to Sell Towns and Regions (Chichester, UK: John Wiley, 1994); Şeyhmus Baloğlu and Ken W. McCleary, "A Model of Destination Image Formation," Annals of Tourism Research 26, no. 6 (2004).

\section{Bios}

Segah Sak is a PhD candidate and works as a part-time instructor at Bilkent University, Faculty of Art, Design and Architecture. She had her BArch degree from Gazi University, Ankara. Her research interests involve urban history, modern Turkish architecture, and the intersection of media and urban studies.

Inci Basa is an assistant professor at Bilkent University, Faculty of Art, Design and Architecture. She made her PhD at Middle East Technical University. She made postdoctoral studies in HTA Bern, Switzerland. Her research subjects involve architectural education, architectural presentation, discourse analysis, and modern Turkish architecture. 